NBER WORKING PAPER SERIES

\title{
STRIKES AND THE LAW IN THE U.S., 1881-1894: NEW \\ EVIDENCE ON THE ORIGINS OF AMERICAN EXCEPTIONALISM
}

Janet Currie

Joseph Ferrie

Working Paper 5368

\author{
NATIONAL BUREAU OF ECONOMIC RESEARCH \\ 1050 Massachusetts Avenue \\ Cambridge, MA 02138 \\ November 1995
}

We thank David Card for generously providing some of the data and Ludwig Chincarini and Chris Kim for excellent research assistance. Sandy Jacoby and participants at the NBER Development of the American Economy Program Meeting in March, 1994 provided excellent comments. Janet Currie thanks the Alfred P. Sloan Foundation for financial support. Joseph Ferrie thanks the Olin Foundation and the Center for Urban Affairs and Policy Research at Northwestern University for financial support. This paper is part of NBER's research programs in Labor Studies, and the Development of the American Economy. Any opinions expressed are those of the authors and not those of the Sloan Foundation, the Olin Foundation, the Center for Urban Affairs and Policy Research, or the National Bureau of Economic Research.

() 1995 by Janet Currie and Joseph Ferrie. All rights reserved. Short sections of text, not to exceed two paragraphs, may be quoted without explicit permission provided that full credit, including $($ ) notice, is given to the source. 


\title{
STRIKES AND THE LAW IN THE \\ U.S., 1881-1894: NEW \\ EVIDENCE ON THE ORIGINS OF \\ AMERICAN EXCEPTIONALISM
}

\begin{abstract}
The origins of American exceptionalism - the apolitical nature of American labor unions compared to their European counterparts - have puzzled labor historians. Recently, the hypothesis has been advanced that organized labor abandoned attempts to win reform through legislation because the reforms did not have the desired consequences. We evaluate this claim using information on each state's legal environment and unique strike-level data on over 12,000 labor disputes between 1881 and 1894. We find that the law affected strike costs and strike outcomes, though not always in the anticipated directions. For example, laws outlawing blacklisting were associated with the increased use of strike breakers, while the legalization of unions, one of the hardest won legislative changes, had little impact. Only maximum hours laws had clearly pro-labor effects. Our results are consistent with the view that the American labor movement abandoned political activism and embraced business unionism because unions found the law to be an inaccurate instrument for effecting change in labor markets.
\end{abstract}

Janet Currie

Department of Economics

University of California

405 Hilgard Avenue

Los Angeles, CA 90024

and NBER
Joseph Ferrie

Department of Economics

Northwestern University

2003 Sheridan Road

Evanston, IL 60208-2600

and NBER 


\section{Strikes and the Law in the U.S., 1881-1894: New Evidence On the Origins of American Exceptionalism ${ }^{\circ}$}

\author{
JANET CURRIE \\ Department of Economics \\ University of California \\ 405 Hilgard A venue \\ Los Angeles, CA 90024 \\ 3102068380 \\ currie@econ.sscnet.vcla.edu \\ and NBER
}

\author{
JOSEPH FERRIE \\ Department of Economics \\ Northwestern University \\ 2003 Sheridan Roed \\ Evanston, IL 60208-2600 \\ 7084918210 \\ ferrio@mw.edu \\ and NBER
}

March, 1994

Revised November, 1995

\section{Introduction}

American trade unions' philosophy of "business unionism" sets them apart from unions in many other countries [Freeman 1989]. Business unionism is characterized by the avoidance of "any permanent commitment to support any political party ..." and "the improvement of wages, hours, and working conditions through the direct efforts of trade unions [rather than] through legislation" [Rees 1977, p. 9]. The origins of this American exceptionalism have long been debated by labor historians. In a provocative recent

\footnotetext{
${ }^{\square}$ We thank David Card for generously providing some of the data and Ludwig Chincarini and Chris Kim for excellent research assistance. Sandy Jacoby and participants at the NBER Development of the American Economy Program Meeting in March, 1994 provided excellent comments. Janet Currie thanks the Alfred P. Sloan Foundation for financial support. Joseph Ferrie thanks the Olin Foundation and the Center for Urban Affairs and Policy Research at Northwestern University for financial support. All opinions are those of the authors and do not necessarily reflect the views of the Sloan Foundation, the Olin Foundation, or the Center for Urban Affairs and Policy Research.
} 
book, Victoria Hattam [1993] defends the thesis that "a strong judiciary created a politically weak labor movement in the United States . . because even successful political campaigns could not ensure a corresponding change in government policy towards labor." She argues that the courts "eviscerated many postbellum labor laws, which left the American Federation of Labor (AFL) disillusioned with the payoffs of political reform" [Hattam 1993, p. ix]. She pays particular attention to the use of the injunction as a weapon against striking workers, arguing'that injunctions "proved to be a formidable weapon in employers' hands and enabled them to constrain a wide array of workers' protests in a single action" [Hattam 1993, p. 161].

In this paper, we evaluate these claims using information about each state's legal environment and unique strike-level data on over 12,000 labor disputes that occurred between 1881 and 1894 in thirteen industrial states.' At this time, virtually all labor law governing organizing and strike activity was made at the state level, and states developed a remarkably varied body of labor law. ${ }^{2}$ This variation across states and over time will allow us to examine the effects of labor law in a way that is seldom possible using contemporary data. We focus on two questions. First, did the legal environment affect strike outcomes? In particular, did apparently pro-labor legislation tip the scales in favor of labor, or was it the case, as Hattam suggests, that these statutes were ineffective? Second, is there evidence that the use of the injunction made negative outcomes for labor more likely?

The rest of the paper is laid out as follows: Section I provides a brief overview of the development of labor law in the late 19th century. Section II describes the data, while Section III discusses the available evidence regarding the effects of the legal environment on the selection of strikes into our sample. We find

\footnotetext{
${ }^{1}$ Though there are numerous descriptive accounts of the development of labor law in the late 19th century [Commons et al. 1918; Commons and Andrews 1927; Tomlins 1985; Friedman 1986], we are unaware of previous studies that systematically examine the effect of these developments on labor-management conflict.

${ }^{2}$ Though the federal Sherman Anti-Trust Act of 1890 was later an important anti-union and anti-strike tool, the federal government played only a small role in shaping labor law during the period we examine. The Sherman Act was first employed against labor in 1894 in the prosecution of Eugene Debs in the Pullman case, but the case was eventually decided on other grounds (In re Debs, 158 U.S. 564, 15 Sup. Ct. 900).
} 
little evidence that the sample of strikes changed in observable respects as the legal environment changed.

Section IV provides the main results on the effects of the labor law on wages, employment, hours worked, and the use of strike breakers. Section V concludes.

\section{The Development of Labor Law in the Late 19th Century}

Three dramatic changes took place in the U.S. economy in the years after the Civil War: the rise of large, centrally-controlled firms to supply new national markets; the growth of national labor organizations; and the increasing regulation of the employment relationship by state governments. The Homestead strike of 1892, which came toward the close of the period we will examine, illustrates all three developments: the strike pitted one of the country's strongest trade unions, the Amalgamated Association of Iron and Steel Workers (with 24,068 members in 1891), against a "modern manufacturing corporation with its practically boundless resources of war," the Carnegie Steel Company [Commons 1918, p. 495], and saw the intervention of the state government (in the form of the Pennsylvania state militia) on behalf of Carnegie Steel.

The rise of large-scale, centrally controlled firms serving national markets has been explored by Chandler [1977] who emphasizes the role of the nation's railroad system calling them "the first modern business enterprises" [p. 81], while Zucker et al. [1992, p. 50] discuss the rise of the trans-national firm more generally. The growth of the trans-national firm was important even for workers who remained in small-scale enterprises: their firms were increasingly in competition with firms that enjoyed significant scale economies. This competition provided the rationale for small-scale employers to seek wage cuts, increased rates of production, and changes in work rules. ${ }^{3}$ The magnitude of the growth in firm size can be seen in measures of

${ }^{3}$ For example, the strike and subsequent lockout of 20,000 Chicago butchers in October of 1887 resulted when an association of meat packers tried to re-impose a ten-hour day on a work force which had won an eighthour day earlier in the year. The employers "justified this action on the grounds that they could not compete with Cincinnati and Kansas City, which operated on the ten-hour system" [Commons 1918, p. 418]. The strike was unsuccessful, as the ten-hour day was reinstituted in November. 
average capital employed by manufacturing firms and manufacturing workers: capital per firm rose fivefold over the second half of the nineteenth century (from just over $\$ 4,000$ in 1850 to nearly $\$ 20,000$ in 1900 , with a doubling just between 1880 and 1900), and capital per manufacturing worker tripled (from $\$ 550$ in 1850 to $\$ 1,700$ in 1900$){ }^{4}$

As the size of firms and the scale of the markets they served grew in the late nineteenth century, membership in unions of laborers organized for collective action also grew. A nascent trade union movement had appeared in the U.S. as early as the 1830 s, embracing roughly 26,000 workers [Lebergott 1972, p. 220]. But these organizations were locally isolated and focused mainly on craftsmen-proprietors: as Commons notes, "it was only during the sixties that labor organizations began to think and act on a lasting national basis" [1918, p. 43]. By the middle of the 1880 s, more than 700,000 workers, both skilled and unskilled, were members of national labor organizations, with most of this growth occurring over just the previous ten years [Lebergott 1972].

With the appearance of large business enterprises and large organizations of workers, the role of the state became crucial. State governments had played a role in labor relations since colonial times, but most of the law dealing with the relationship between employers and their workers before the Civil War consisted of attempts by state courts to fit precedents stretching back to the fourteenth century to the new circumstances of the nineteenth century. It was not until the 1880 s and 1890 s that state legislatures and courts were regularly called upon to intervene in labor disputes and developed new legal means to do so.

\footnotetext{
4Tese figures were calculated from U.S. Bureau of the Census [1902, Table 1, p. 982]. The second half of the nineteenth century saw rising prices (measured by the Consumer Price Index) during the Civil War, but persistently falling prices through 1900. The CPI shows no net change between 1850 and 1900 [U.S. Bureau of the Census 1975, Series E 135]. The average mumber of employees per establishment shows less striking growth (rising from under 8 in 1850 to just over 11 in 1900), but these figures are dominated by the persistence of many small-scale manufacturing proprietorships, and mask the rise in the number of firms at the very top of the size distribution [U.S. Bureau of the Census 1902, Table 1, p. 982].
} 
The first aspect of the employment relation addressed was the length of the workday. States passed legislation to regulate the hours of women and children throughout the nineteenth century [Goldin 1988], but they were more cautious in regulating the hours of men. No argument could be made for regulating the hours of men on purely social grounds as was true for women and children. And courts had held that the freedom of contract prevented states from dictating the maximum number of hours employees could work each week [Stimson 1895, p. 43]. Three strategies emerged in response to these constraints.

The first was regulation of employees' hours when the state was a direct party to the labor contract, as when states employed workers themselves or hired contractors who in turn hired workers. New York passed such legislation in 1870 [Friedman 1973, pp. 493-4]. The second was regulation of specific industries, particularly those in which worker fatigue could result in injury to the workers themselves or to others because the work involved heavy machinery. New York's maximum hours legislation for railroad workers in 1888 and 1892 fits into this category [Friedman 1973, pp. 493-4]. The third approach was prescribing a maximum number of hours that employees could be forced to work "in the absence of any agreement to the contrary." Since most labor contracts specified both a wage and a work schedule, this last provision was relatively toothless, but may have signalled at least some concern on the part of the state for workers' interests. Five of the states we examine below had at least one of these types of legislation on the books before 1880 (Connecticut, Illinois, Maine, New Hampshire, and New York), and all of the states we examine except Delaware had such laws by 1890 .

The explicit legalization of unions by state legislatures came relatively late in the nineteenth century. Throughout much of the period, the court's approach to organized labor was based on the doctrine of conspiracy in English common law. This doctrine had its roots in the Statute of Laborers of 1349 (22nd Edward III) which specifically forbade groups of workers from striking to raise their wages, and made any attempt to do so a criminal conspiracy. The statute, designed in the wake of the Black Death to set wages and prevent laborers from raising their wages by refusing to work, was later embodied in the Elizabethan Statute 
of Artificers (5th Elizabeth, Ch. 4). On the basis of this and subsequent statutes, the Journeyman Tailors case (8 Mod., 11) in 1721 established that attempts to raise wages by forming "combinations" were criminal conspiracies. Initially, in two cases in Pennsylvania and two in New York, U.S. state courts followed this precedent and held that trade unions were illegal combinations, criminal conspiracies designed to accomplish an illegal end - raising the wages of their members. ${ }^{5}$

The use of the Journeyman Tailors case as a precedent in these early American cases is surprising, since there had been no law regulating wages in the U.S. since the Revolution. ${ }^{6}$ An authority on nineteenth century American labor law writing in 1896 noted this anomaly: "But in this country, wages never having been fixed by law, the case should never have been followed" [Stimson 1896, p. 202]. These early American decisions were made in inferior courts. When the first superior court decision was rendered, in 1842 in Commonwealth v. Hunt (15, 4 Met., 111), the Massachusetts supreme court discarded the Journeyman Tailors precedent and established for the first time the per se legality of labor combinations and strikes [Stimson 1896, pp. 203-4]. The result was a sharp reduction in the number of union conspiracy trials in the 1850 s and early 1860s [Friedman 1973, pp. 486-7].

However, after the Civil War labor unrest increased, and many strikers again faced prosecution under anti-conspiracy laws, and unions made the repeal of the conspiracy doctrine one of their highest priorities [Hattam 1993, pp. 20, 72, and 140-1]. Under pressure from the Knights of Labor (KOL) and other less radical organizations springing up in many cities and industries, most state legislatures had recognized the right of unions to exist and to strike, and had established procedures allowing labor organizations to

\footnotetext{
${ }^{5}$ These cases were the Philadelphia Cordwainers case (1806), People v. Melvin (2 Wheeler Criminal Cases, N.Y., 262, 1809), the Journeyman Cordwainers of Pittsburgh case (1811), and People v. Fisher (14 Wendell, N.Y., 1, 1835).

${ }^{6}$ Before the revolution, both Massachusetts and Virginia had attempted to set wages by statute [Hughes 1976 , pp. 98-9].
} 
incorporate. Before 1880 , the only states in our sample that had passed such laws were New Jersey, New York, and Pennsylvania; by 1893 , five other states had done so.

However, even in jurisdictions where the interpretation of anti-conspiracy laws left workers free to strike, workers accused of intimidating other workers or organizing boycotts continued to be prosecuted under anti-conspiracy laws. Many states formalized these laws into statues outlawing intimidation and boycotts. Between 1887 and 1897 , six states also limited the behavior of the other party to labor disputes by banning employer blacklisting of workers who joined unions or went on strike.

Finally, the late 1880 s and early 1890 s saw a sharp rise of the use of the injunction against striking workers. Both federal and state equity courts had issued injunctions to prevent injury to property throughout the nineteenth century. But it was not until courts recognized that the right of employers to conduct business was a form of "property at risk of injury" in a work stoppage that injunctions were routinely issued to bar work stoppages altogether, to prevent certain forms of behavior by striking workers (such as boycotting or aggressive picketing), or to end stoppages by requiring that workers return to work. The injunction was seen as a powerful weapon against labor stoppages: unlike conspiracy prosecutions which took time and required at least a modicum of evidence, injunctions could be granted after a brief hearing and a mere assertion that harm to a firm's commerce was imminent. Hattam [1993, p. 163] notes that "The AFL and other union leaders understood all too well the demoralizing impact of the injunction and renewed their efforts to check the courts' power"; she describes a twenty year campaign by organized labor to overturn the injunction as a legal weapon.

\section{The Data}

The last decades of the nineteenth century present a unique opportunity to assess the impact of labor law on strike behavior: in addition to the tremendous heterogeneity in the legal environment both across states and within states over time that we have noted above, the U.S. Commissioner of Labor compiled two 


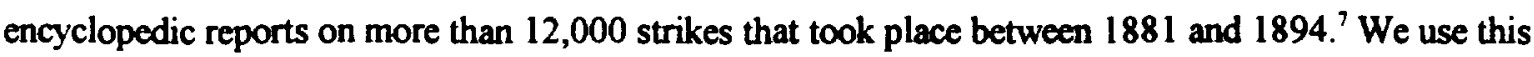
information to evaluate the success of organized labor's attempts to improve its bargaining position relative to employers through the political process. In order to do so, we examine the impact of state labor law on strike costs (such as strike length and the number of worker days lost due to strikes) which are borne by both workers and employers and strike outcomes (such as changes in hours, wages, and employment, and the use of replacement workers) which were of particular concern to workers. We will offer no new theory about the formation of union objectives. ${ }^{8}$ Instead, we take organized labor at its word when it says it desired a particular change in the legal environment (such as changes in the conspiracy doctrine) and ask whether that change apparently desired by labor produced outcomes favorable to labor, through either reducing strike costs or improving strike outcomes.

We have drawn information about the labor law in effect in each state between 1880 and 1900 from published state statutes, proceedings of state legislatures, and compilations of judicial decisions in labor disputes brought before the courts. ${ }^{9}$ We examine five categories of labor law: 1 ) whether the right to form unions is formally recognized or procedures were established allowing unions to incorporate; 2) whether a maximum hours law exists for any group of male workers; 3 ) whether there is a law against the intimidation of strike breakers or characterizing the intimidation of strike breakers as a "conspiracy," or there is a law

' Our analysis of the impact of labor law in this period is also facilitated by the absence of administrative agencies to enforce labor law. In contemporary analyses of the effect of labor law, it is often necessary to address the issue of enforcement (particularty the resources devoted to enforcement) by administrative bodies such as the National Labor Relations Board. Though several state governments established agencies to arbitrate labor disputes between 1880 and 1900, most of the labor law we will consider was adjudicated as criminal law. For example, a striking worker who had been blacklisted by an employer could seek relief directly through the state's criminal courts if blacklists had been outlawed. The same would be true for an employer suffering a boycott. The only impediments that would prevent a particular law from having an effect would be the unwillingmess of an aggrieved party to seek a prosecution, the unwillingness of a prosecutor to seek an indictment, or the unwillingness of a judge or jury to convict.

\footnotetext{
${ }^{8}$ Readers interested in these issues should consult Farber [1986] and Kennan [1986].

${ }^{9}$ These sources are described in detail in the Data Appendix.
} 
against labor-organized boycotts; 4) whether there is a law against the blacklisting of union members or strikers by employers; and 5) whether a court has issued and sustained an injunction sought by an employer against striking workers. ${ }^{10}$ Distilling each state's labor law into an empirically tractable number of "law variables" in this way necessarily involves a simplification of the complex legal environment described above. We believe we have captured in at least a crude way the most salient features of that environment.

Table 1 summarizes the legal environment in each state in terms of these categories. A date indicates that the relevant law was passed at that time, while "no law" indicates that there was no law in effect as of 1900. The table illustrates both the tremendous heterogeneity in state legal environments and the difficulty in identifying "packages" of laws that tended to go together. For example, several states both recognized unions and outlawed the intimidation of strike-breakers. Table 1 also shows that in several large states, laws banning intimidation and boycotts were passed simultaneously, which makes it difficult to identify the separate effect of these laws. Since both laws were intended to place limits on worker's right to organize, we have grouped them together in our empirical work. Finally, the table illustrates the dramatic changes in the legal environment that occurred after the notorious Haymarket Riot of 1886 . Between 1887 and 1894, four states adopted maximum hours laws for at least some groups of workers. Eight states had such a law prior to 1886. Illinois, one of the states hardest hit by the strike wave of 1886, passed an innovative law outlawing both boycotts and blacklisting in 1887 .

The data that will allow us to assess the effects of these laws are drawn from two sources: the Third Report and Tenth Report of the U.S. Commissioner of Labor [U.S. Commissioner of Labor 1888; U.S.Commissioner of Labor 1896]. The reports describe strikes in the years 1881 to 1896 and in 1887 to 1894, respectively. Investigators combed through newspaper reports and other contemporary sources in order to compile an initial list of strikes. They then conducted interviews in each location where a strike was

${ }^{10}$ We have included injunctions in both federal and state courts, and injunctions enjoining strikers from committing specific acts (such as picketing), as well as injunctions that simply forced strikers to return to work. 
reported to obtain detailed information about each strike, as well as information about other strikes. "For each strike, the reports include the beginning and ending dates of the strike, the industry and occupation of the workers, the location, the number of male and female workers in the firm before the strike, the number of workers involved, the hours of work before and after the strike, whether the strike was authorized by a union, and whether replacement workers were used. The Third Report also recorded workers' wages and firms' employment levels before and after strikes. Compared to contemporary strike data sets, this is a very rich source of information about industrial disputes.

We have coded information from thirteen states drawn from three broad regions: 1) the Midwest (Illinois, Indiana, Michigan, and Ohio); 2) New England (Connecticut, Maine, Massachusetts, and New Hampshire); and 3) the Middle Atlantic states (New Jersey, New York, Pennsylvania, Delaware, and Maryland). These states were chosen because they experienced almost $90 \%$ of all reported strikes and because they exhibit great variation in labor law.

We focus on six measures of strike outcomes: the percent changes in wages, employment, and hours; whether strike replacements were used; the fraction of workers replaced conditional on the use of replacements; and the unconditional mean fraction of the workforce replaced. We also examine two measures

${ }^{11}$ By way of comparison, contemporary strike data are compiled from newspaper reports, and only include strikes involving over 1000 workers. Edwards [1981] and Griffen [1939] both contain extensive discussions of the reliability of the Commissioner of Labor's data collection procodures. A recent re-examination of the data from the Third Report and the Tenth Report for Terre Haute, Indiana, however, finds that only half of the strikes for which there exists a record were included [Bailey 1991]. The strikes that were omitted appear no different (in size, industry, or duration) from those that were included. A second problem with the reports is that the Third Report used the enterprise as the unit of observation (i.e. related strikes at different plants were counted as separate strikes). The Tenth Report used a broader definition of a strike that counts strikes that began at roughly the same time over similar issues as a single dispute. A re-analysis of the earlier data conducted for the TwentyFirst Report concluded that the number of strikes had been overstated by $30 \%$ in the Third Report. However, it is not clear how religiously the new definition was applied in the Tenth Report. We find many instances in which apparently related strikes were nonetheless coded as separate strikes. Hence, we have chosen to treat the data from the two reports in the same way, and to rely on the inclusion of year effects to capture systematic differences in strike prevalence associated with changes in reporting conventions over time. See Card and Olson [1994] for additional discussion of these issues. 
of strike cost: strike duration and the number of working days lost. In general, increases in wages, smaller post-strike employment losses, reductions in hours, reduced use of strike replacements, and shorter strikes could all be regarded as positive outcomes for labor. Reduced strike costs represent a Pareto improvement in that they are also a benefit to employers. Note that wage and employment changes are only available for the 1881 to 1886 period. $^{12}$ We use nominal wages since the relevant time interval is short, and it is difficult to construct accurate price indices for the period. In addition to these measures, we examine the extent to which strikes were authorized by unions as one indicator of how the legal environment might have influenced the composition of our sample.

Table 2 describes the strike-level data. Our measure of the extent to which strike activity was unionauthorized appears in column 1. Strikes were most likely to be union-authorized in New York, and in the building trades, tobacco, and food processing and brewery industries. Columns 2 and 6 of Table 2 show the distribution of pre-strike employment and the changes in employment that occurred following strikes.

Columns 3 to 5 give the fraction of strikes in which strike replacements were employed, the fraction replaced conditional on strike breakers being used, and the overall mean percentage replaced.

The use of strike breakers was very common, especially in Delaware and in some industries (printing, publishing, and telegraph, food processing and brewing, transportation, and the residual category) where strike breakers were used in over half of all strikes. When strike replacements were used, typically about a quarter of the pre-strike workers were replaced. Overall, approximately $11 \%$ of striking workers were replaced, although this proportion was as high as $23 \%$ in the printing, publishing, and telegraph industry. Column 6 shows the difference between post-strike and pre-strike employment. As noted above, post-strike employment appears only in the Third Report, so it is unavailable after 1886. Except in Delaware, the overall

\footnotetext{
${ }^{12}$ Table 2 shows that where measures of strike outcomes are available in both reports, there is continuity between the information contained in the Third Report (1881 to 1886) and the Tenth Report (1887 to 1894). Nevertheless, possible changes in reporting conventions between the two reports provide a further justification for the inclusion of year dummies in our regression analysis.
} 
employment effect of strikes was small. Hence, the main threat to striking workers was that they would be replaced, not that their establishments would be "down-sized" or shut down.

Columns 7 through 10 of Table 2 show the mean hours worked and wages before the strike, and the mean percentage change in hours and wages after the strike. The average strike was accompanied by a very small change in hours. A $0.6 \%$ reduction in hours at an establishment with a 58 hour week is a reduction of less than half an hour. The strike wave of 1886 was associated with somewhat larger average percentage reductions in hours - at the mean of 60 hours per week, a $1.7 \%$ reduction amounts to an average reduction of 1 hour per week. Not surprisingly, the largest reductions occurred in the industry with the longest prestrike hours: printing, publishing, and telegraph where workers averaged 72 hours per week before a strike. Table 2 implies that strikes in this industry were associated with average reductions of almost 3 hours per week. Columns 9 and 10 indicate that strikes in the early years of the sample were also associated with modest increases in wages (except in Delaware). The largest percentage wage increases were in New York $(5.6 \%)$ and in the food processing and breweries industry (7.5\%).

The final two columns of Table 2 show median strike durations and numbers of working days lost (calculated as the product of employment before the strike and the number of strike days). We show the medians because the distributions are skewed to the right by a few particularly long or large strikes. Because of the skewed distribution of strike lengths or sizes, we will use the logarithms of these variables as the dependent variables in our regression analysis. The median strike lasted 7 days and involved 765 working days lost. The median duration reached a peak of 14 days in 1885, and then declined back to 6 or 7 days after 1886. The median number of working days lost shows a similar temporal pattern. It is interesting to note that in New York, where most strikes were union-authorized, the median strike was short and involved relatively few days lost.

Table 3 shows how the same measures of strike outcomes and costs vary with the legal environment. Since we know the date each strike began, we can group strikes according to whether a particular type of law 
was in effect on the day the strike began. Strikes were more likely to be authorized by unions in jurisdictions where unions were legal, maximum hours legislation existed, intimidation of strike breakers or the use of boycotts were illegal, blacklists were banned, and the injunction had not yet been used against labor (column 1) ${ }^{13}$ It is understandable that pro-labor legislation was associated with more union-sanctioned strike activity. However, it is surprising that anti-union laws like those against the intimidation of strike breakers or the use of boycotts were also associated with a higher probability of union-authorized strikes. These measures may have reduced the costs to unions of sanctioning strikes by reducing the likely level of violence. ${ }^{14}$

\footnotetext{
${ }^{13}$ For injunctions, we do not presently know the exact date at which an injunction was first issued by a court in a given state. We know only the year in which an injunction was first issued and sustained in that state. The "injunction used" category therefore includes strikes in a state that occurred in the calendar year after the calendar year in which an injunction was issued and sustained in the state. We are in the process of refining this indicator of the legal environment to provide more accurate information on the date at which the injunctions were issued.

14 The laws against intimidation of non-strikers and against boycotts also point to the difficulty of unambiguously classifying laws as either pro-labor or anti-labor. As Hattam [1993, p. 144] notes, New York revised its conspiracy laws four times: in 1870, 1881, 1882, and 1887. The Workingmen's Assembly "campaigned actively for three of the four statutes and claimed credit for these
} legislative victories" [p. 144]. The first revision legalized

the orderly and peaceable assembling or cooperation of persons employed in any profession, trade, or handicraft, for the purpose of securing an advance in the rate of wages or compensation for the maintenance of such rate [Laws of the State of New York, Chap. 19, p. 30, February 17, 1870].

The second revision formally inserted this provision into the state's penal code. We have classified this as a law legalizing unions. The third revision explicitly described the conditions under which the activities of strikers amounted to intimidation or constituted a boycott:

A person who with a view to compel another person to do or abstain from doing an act which such person has a legal right to do or abstain from doing wrongfully and unlawfully,. . . uses violence or inflicts injury upon such other person or his family or, a member thereof, or upon his property or threatens such violence or injury; or deprives any such person of any tool, implement, or clothing, or deters him in the use thereof; or uses or attempts the intimidation of such person by threats or violence is guilty of a misdemeanor. ... A person who willfully and wrongfully commits any act that seriously injures the person or property of another. . . is guilty of a misdemeanor. But nothing in this code contained shall be so construed as to prevent any person from demanding an increase of wages or from assembling and using all lawful means to induce employers to pay such wages to all persons employed by them as shall be a just and fair compensation for services rendered [Laws of the State of New York, Chap. 384, p. 545, June 30, 1882]. 
Similar patterns hold for the size of striking firms (column 2): jurisdictions with legal unions, laws outlawing boycotts, intimidation, and blacklists, and no history of anti-labor injunctions all had smaller prestrike employment levels. Maximum hours laws, however, are an exception to this pattern: they were associated with somewhat larger pre-strike employment levels.

The third column of Table 3 shows that employers were more likely to use strike breakers in jurisdictions in which the injunction had been used. However, conditional on strike breakers being used, a smaller fraction of workers were replaced in these jurisdictions. Overall, as column 5 shows, liberal labor laws (legal unions, maximum hours laws, and illegal blacklists, and no recent use of the injunction against labor) were associated with a slightly higher probability of being replaced, as were laws outlawing intimidation and boycotts.

Columns 6,8 , and 10 of Table 3 indicate that although wage gains were higher in jurisdictions with liberal labor laws and in those that outlawed intimidation and boycotts, there was little variation across legal environments in post-strike employment losses in the 1881 to 1886 period, or in hours changes over the whole period. It is interesting to note the union/non-union wage differential of approximately $10 \%$ in prestrike wages between striking firms in union-legal jurisdictions and striking firms in other jurisdictions (\$1.99 vs. \$1.82) shown in column 9 , since this estimate is in line with current estimates of union/non-union wage differentials [Lewis 1986]. Wages were also higher for striking firms in jurisdictions with maximum hours laws and in jurisdictions in which intimidation and boycotts had been outlawed. However, they were lower in jurisdictions in which the injunction had been used. These data indicate that most strikes resulted in $1 \%$ to $3 \%$

We have classified this as a law outlawing intimidation and boycotts (it clearly addresses the former; the clause protecting "property" was applied to the right to continue to do business and was used to prosecute strikers engaged in boycotts). Labor's support of it, however, suggests that this law may have been viewed as a vehicle for limiting the prosecutions of strikers, by removing intimidation and boycotts from scrutiny under the common law, which was subject to capricious interpretation, and making these issues of statute law subject to less judicial discretion. 
increases in wages. Wage increases were highest in jurisdictions with legal unions and maximum hours legislation, and where boycotts and intimidation of strike breakers were illegal.

Turning to strike costs in columns 11 and 12 , the outlawing of intimidation, boycotts, and blacklists was associated with reduced strike duration. These laws were also associated with reductions in the number of strike days lost, as were legal unions and maximum hours laws.

In summary, Table 2 suggests that there were large variations in all our measures of strike costs and outcomes by state, year, and industry. Table 3 indicates that there was also a great deal of variation in these measures across different legal environments. On the whole, liberal labor laws were associated with lower strike costs, higher post-strike increases in wages, and a greater probability of workers being replaced. We will examine whether these patterns persist when we control for state, year, and industry differences. Before this question can be addressed, however, we must examine the effect of legal changes on the composition of our sample.

\section{Sample Selection}

Our data on strike outcomes pertain only to firms in which a strike occurred, so a change in the legal environment could have an impact in either of two ways: 1) by changing the risk that some types of firms are likely to experience a strike, holding constant the probability that a firm of that type experiences a particular strike outcome; or 2) by changing the probability of a particular strike outcome for firms already at risk to experience a strike. Suppose for example, that legislation permitting unions encouraged strikes at small firms, and that other things equal, strikes at small firms are more likely to result in worker losses. Then changes in the composition of striking firms resulting from permissive legislation could mask a positive effect of prolabor legislation on strike outcomes, conditional on the strike occurring.

We address this selection issue in three ways. First, we examine the relationship between strike activity at the state/year level and the legislative environment using both graphical and regression methods. In 
order to do so, we construct state/year measures of the number of strikes, the number of strikers, and the number of days lost due to strikes by aggregating our strike-level data up to the state/year level. Second, we merge the strike-level data with information from the 1880 and 1890 Censuses of Manufacturers and ask how the legislative environment was related to differences between the observable characteristics of striking firms and those of the average firm in the state. Finally, we ask whether the legal environment was related to the probability that a given strike was union-authorized.

Our three measures of strike activity are plotted separately for each state in Figures 1 through 13. Legislative changes are indicated on the figures. These figures can be examined to gain a sense of: 1) whether changes in aggregate strike activity preceded changes in legislation; and 2) whether aggregate strike activity seems to have changed appreciably following changes in legislation.

Several patterns are apparent. The first is that the legalization of unions is preceded by a fall in our measures of strike activity and followed by a rise. This is the case in Massachusetts, Maryland, and Ohio. A second apparent regularity in the data is that the imposition of a maximum hours law is preceded by a rise in strike activity and followed by a fall in strike activity. This pattern can be seen in all seven of the states that passed maximum hours laws between 1881 and 1894 (Indiana, Massachusetts, Maryland, Michigan, New Jersey, Ohio, and Pennsylvania). There are no clear patterns for laws banning boycotts, intimidation, or blacklisting, or for the use of the injunction. For example, the banning of boycotts or intimidation followed a rise in strikes and preceded a fall in two states (Indiana and New York), while such legislation followed a fall in strike activity and preceded a rise in Illinois. The law in New Hampshire appears to have produced no effect, though it, too, followed a period of high strike activity.

There is thus some evidence here that aggregate strike activity causes, or at least precedes, some law changes (legalization of unions and imposition of maximum hours laws), though aggregate strike activity shows no systematic relationship to other aspects of the legal environment (laws banning boycotts, intimidation, or blacklists, and the use of injunctions). However, none of these law changes seem to have been 
associated with a permanent change in the level of aggregate strike activity. Further, in the two states that experienced no change in these laws during the 1881 to 1894 period (Connecticut and Delaware), there were cycles in strike activity at least as pronounced as those associated with legal changes in the other states. These results suggest that if changes in the legal environment had a role in causing changes in strike activity, that role was probably both small and of short duration.

Table 4 adopts a more parametric approach and examines aggregate strike activity using OLS methods. In addition to the five law variables discussed above, these models include dummy variables for each state and year, as well as state-specific time trends. These dummy variables capture fixed characteristics of states and years that may be associated with organizing activity, as well as possible state-specific changes in attitudes towards organized labor, or in labor strength over time. We also control for the industry composition of each state/year cell by averaging the individual-level industry dummies up to the state/year level. Table 4 suggests that the legal environment had little effect on aggregate-level strike activity. The only exceptions are the significantly negative effects of maximum hours laws on the number of strikes and strike days lost.

In Table 5, we adopt a different approach and look at how the pre-strike characteristics of individual striking manufacturing firms in 1881 and 1891 differed from the characteristics of the average firm in the Censuses of Manufacturers in 1880 and $1890 .^{15}$ These regressions control for the state, year, and industry of

is We use data from 1881 and 1891 because data for striking firms from 1880 are unavailable. For comparability with the Census data, the regressions used in columns 1 to 3 of Table 5 exclude strikes in mining, printing, publishing, telegraph, public ways or works construction, transportation industries, building trades, and stone quarries. The number of firms and the numbers of male and female wage earners by state for 1880 and 1890 are contained in the 1900 Census of Manufacturers [U.S. Bureau of the Census 1902, Table 1, pp. 982-8]. The average employment per establishment and fraction female in the labor force were calculated for each state directly from these figures. Average daily hours of labor were not reported in the published volumes of the 1880 Census of Manufactures. These data were, however, collected as part of the census, and were included in the Atack and Bateman sample of firms from the manuscript schedules of the census [Atack and Bateman 1990]. Comparable figures for daily hours in 1890 were obtained from the published returns of the 1890 Census of Manufacturing [U.S. Census Office 1892-1897, Table 8, pp. 654-738]. In 1890, hours were reported only for a subset of industries, however. From this subset, nine industries were selected that covered most of employment 
the strike, and for location in one of 18 large cities, as well as for the five law variables. ${ }^{16}$ Table 5 shows that the typical striking firm was about 244 workers larger than the typical manufacturing firm. It also had a slightly lower fraction of female employees and had lower weekly hours. Column 1 shows that the legal environment appears to have had little effect on the pre-strike size of striking firms. Column 2 indicates, however, that the use of the injunction was associated with a marginally significant increase in the fraction of female employees at striking firms relative to the average. The largest changes appear to have been in the prestrike hours of striking firms, although there is no clear pattern associated with pro-labor laws: laws permitting unions reduced the hours of striking firms, maximum hours laws increased them, and anti-blacklist laws had a marginally significant negative effect.

Finally, in column 1 of Table 6, we examine the effect of the legislative environment on the probability that a union authorized a particular strike. In addition to the state, year, city, and industry dummies and the state-specific time trends described above, this regression controls for the log of pre-strike employment, pre-strike hours, the fraction female in the firm, and the number of strikes in the same state/year/industry cell. Although unions were much more likely to authorize strikes in firms with low fractions of female workers, and they were more likely to have authorized a given strike in years with many strikes (evidence of union-sponsored strike "waves"), we find little effect of the legal environment. The one exception is that previous use of the injunction in a state made union authorization of strikes less likely.

\footnotetext{
in manufacturing (agricultural implements, boots and shoes, carriages and wagons, cheese, butter, and condensed milk, flouring and grist mill, leather, paper, slaughtering and meat packing, and wholesale slaughtering excluding meat packing). Average daily hours were calculated by taking the establishment-weighted average of the reported figures for these nine industries (similar results were produced using employment as weights). The set of industries drawn from the Atack and Bateman sample was restricted to the nine industries used in 1890 for this calculation. For both 1880 and 1890 , the average daily hours figure used was the figure for May to November if the strike occurred in that period and the figure for November to May if the strike occurred then.

${ }^{16}$ The major cities are: Boston/Cambridge, Brooklyn, Baltimore, Chicago, Cincinnati, Cleveland, Detroit, New York, Springfield (Illinois), Springfield (Massachusetts), Worcester, Fall River (Massachusetts), Indianapolis, Lynn, Newark, New Haven, Philadelphia, and Pittsburgh.
} 
In summary, once we control for differences between states, years, and industries, there is little evidence of any systematic effect of the legal environment on aggregate strike activity or on the difference between striking firms and average firms in a state and year. The one exception is that strikes were less frequent in jurisdictions with maximum hours laws. We also find no evidence that strikes were more likely to be union authorized in jurisdictions with favorable legal environments, although they were less likely to be authorized in jurisdictions where the injunction had been used. While the sample of striking firms may change with the legal environment in some unobservable way, changes in the law have no obvious observable effect on our sample of strikes. These findings suggest that, with few exceptions, we can interpret differences in strike outcomes associated with differences in the legal environment as true effects of the law rather than as artifacts of changes in the composition of striking firms.

\section{Effects of the Legal Environment on Strike Outcomes}

In this section we turn to the strike-level data and examine the effects of the legal environment on strike costs and strike outcomes. The discussion above suggests that pro-labor legislation such as laws legalizing unions, maximum hours laws, and laws outlawing blacklisting should have produced favorable effects on strike outcomes, while anti-union laws such as those outlawing intimidation and boycotts and use of the injunction should have produced negative effects. The impact of the legal environment on strike costs is less clear, since these are borne by both workers and employers, although some models of strike activity suggest that the reduction of uncertainty surrounding the legality of organizing and strike activity could be expected to reduce strike costs [Currie and McConnell 1992; Kennan 1986].

In order to control for unobserved characteristics of firms that may be correlated with strike outcomes, all of our regressions include indicators for the state, year, industry, and city of the strike, and for state-specific time trends. Most of our regressions also control for pre-strike employment, the number of hours worked per week before the strike, and for the pre-strike fraction of female workers. As we will show, 
these variables had important and interesting effects on strike outcomes. Unless otherwise noted, however, their exclusion does not affect the estimated coefficients on the law variables. We do not include the wage at the beginning of the strike since it is not available for the entire period. ${ }^{17}$ Finally, we include the number of other strikes in the state, year, and industry in order to control for any omitted characteristics that might be correlated with strike waves. ${ }^{18}$

Columns 2 and 3 of Table 6 show regressions using our two proxies for strike costs: strike duration and the number of working days lost. Since the distributions of these variables are skewed by the occurrence of a few long strikes, we take logarithms of the dependent variables. Pre-strike employment is not included in the regression on the number of working days lost, since there is a mechanical relationship between the two variables.

The estimates in columns 2 and 3 indicate that maximum hours laws were associated with both significantly shorter strikes and fewer days lost. This finding is consistent with the regressions on aggregate strike activity shown in Table 4 which showed that fewer aggregate working days were lost in jurisdictions with maximum hours laws. The significant effect of maximum hours legislation on strike length and days lost is consistent with evidence using contemporary data that strikes are longer in states that do not recognize public sector workers' collective bargaining rights [Currie and McConnell 1992].

The estimates in column 3 also indicate that the banning of intimidation and boycotts was associated with significantly more days lost. This suggests that the impact of this type of law differs according to which measure of strike costs is used (strike length or worker days lost due to the strike). However, when pre-strike

17 Results for the 1881 to 1886 subsample were similar whether or not wages were included, although including the wage caused the coefficients on size, hours, and the fraction female to fall in absolute value. This is to be expected, since firm size and wages are strongly positively correlated, while hours and fraction female are strongly negatively correlated with wages in these data.

${ }^{18}$ We also estimated regressions that included the number of workers involved in strikes as a fraction of the state's population, rather than the number of other strikes in the state/industry/year. The results were similar to those reported below. 
employment is included in the model of the number of days lost, (i.e. the same specification is used for both outcome variables), the estimated coefficient on intimidation/boycott drops to 0.16 with a $t$-statistic of 1.41 . Hence, the results for duration and days lost are consistent and do not indicate any robust effect of laws banning intimidation and boycotts on strike costs.

Finally, both strike length and the number of worker days lost in strikes were significantly higher in states where an injunction had previously been issued. In both specifications, the use of the injunction increased strike costs by slightly more than twenty percent. This result is somewhat surprising, since the injunction was often used not just to prevent striking workers from engaging in specific activities (such as aggressive picketing or the distribution of leaflets) but also to force workers to return to work, with union leaders subject to contempt penalties for failure to comply. Strikes that were actually enjoined are likely to have been shorter than they would have been otherwise. However, by creating additional uncertainty about the likely outcome of the strike, the threat of an injunction may have actually made it more difficult for parties to a dispute to settle. Since longer strike durations impose costs on both workers and firms, it remains to be seen if there was some compensating benefit to employers that accounted for their enthusiasm for the injunction as an anti-strike weapon.

Table 7 explores the effect of legislation on strike outcomes. These models use the same variables as those in Table 6. The one exception is that in models of the percent change in employment, we exclude prestrike employment, and similarly we exclude pre-strike wages and pre-strike hours in regressions on the percent changes in wages and hours, respectively. Regressions that included these pre-strike variables produced very similar estimates to those shown below. ${ }^{19}$

The first column of Table 7 shows that the legal environment had no discernable effect on the percent change in hours following strikes. Column 3 shows that we were also unable to find any effect of the law on

\footnotetext{
${ }^{19}$ The only exception is that the fraction female has a positive effect on the percent change in employment when pre-strike employment is included.
} 
the change in employment after a strike over the 1881 to 1886 period when we have data on pre-strike and post-strike employment. The results in column 2 offer the first evidence that the legal environment had an effect on strike outcomes: maximum hours laws were associated with a wage increase of $6 \%$ after strikes.

The legal environment seems to have had the strongest impact on the use of strike replacements, although the direction of the effects is sometimes surprising. ${ }^{20}$ For example, laws legalizing unions increased the probability that strike breakers were used, but reduced the fraction replaced conditional on strike breakers being used. On balance, as column 6 shows, the legalization of unions had no significant effect on a striking worker's probability of being replaced. Laws banning blacklists, also an apparently pro-labor measure, increased the use of strike breakers by 6 percent without any change in the fraction replaced conditional on replacement. The net effect was a 7 percent increase in the probability of being replaced.

Of the pro-labor laws we have examined, only maximum hours laws were linked to reductions in the probability that strike breakers were used, without any change in the fraction replaced. Hence, they reduced striking workers' probabilities of being replaced. We saw in Table 4 that maximum hours laws were the one type of law associated with significant changes in aggregate strike activity. It is possible that the positive effect of maximum hours laws on post-strike wages and the use of replacements reflects a change in the composition of strikes, rather than a change in the probability of union success, given a strike. Since maximum hours laws were associated with reduced strike activity, it is possible that the strikes that were "prevented" by this law change were those that would have resulted in poor outcomes for labor.

Laws banning intimidation and boycotts had the expected negative impact on labor: these laws were associated with a marginally significant increase in the mean fraction of workers replaced by strikebreakers. These laws also increased the number of strike days lost in column 3 of Table 6 . Taken together, these

\footnotetext{
${ }^{20}$ The regression in column 4 uses OLS on the binary dependent variable (whether strike replacements were used) to enhance the comparability of the estimated coefficients across the columns of Table 7 . When a logistic regression was estimated instead, the same qualitative results were obtained.
} 
findings suggest that there was a tradeoff between the intensity with which strikes could be fought and strike length.

Laws legalizing unions had only weak effects despite the fact that the legalization of trade unions was a key union demand during much of the 1870 s and 1880 s - for example, the incorporation of trade unions was either the first or second plank in each of the Federation of Organized Trades and Labor Unions platforms [Hattam 1993, p. 133]. This is a remarkable result since labor unions were usually the authors and the strongest proponents of the legislation that brought them legal status. One explanation of this finding is that legal status brought costs as well as benefits: though legalized unions were free to strike without fear of a conspiracy prosecution, they were also vulnerable to attack in the courts once they became legal entities. The legalization of unions provided them with a shield, but it also made them more obvious targets. ${ }^{21}$

It is remarkable that the existence of maximum hours laws for some groups of male workers had such significant effects on strike outcomes, since, as discussed above, many of these laws appear to have been relatively toothless in achieving their immediate goal of reducing the length of the workweek. However, Goldin [1988] found that the passage of maximum hours laws for women also reduced hours for men. She attributes some of this effect to a general sentiment among workers in favor of shorter hours. Perhaps labor law affects labor markets not so much through enforcement as through the establishment of new social norms. Heckman and Paynor [1989] make a similar argument regarding the effects of Civil Rights legislation on the employment of blacks in southern textile mills.

Fixed costs of employment provide another possible explanation for the effect of maximum hours laws on the use of replacements - in the presence of fixed costs, employers facing maximum hours laws might choose to hire fewer, better quality workers, who were more difficult to replace. The difficulty of replacing such workers might explain the shorter strike durations observed in these jurisdictions. The

${ }^{21}$ We are grateful to Sandy Jacoby for suggesting this interpretation. 
significantly larger wage changes in firms with longer pre-strike hours also supports the fixed costs interpretation, since employers were clearly willing to pay more to have workers work longer hours.

The negative impact of anti-blacklist laws is our most puzzling finding. Freeman [1988] speculates that the extent of employer resistance to unions is positively related to the costs to the firm of union activity. If liberal labor laws such as those outlawing blacklists increased the effectiveness of organized labor, they may have had the unintended consequence of intensifying employer resistance. Table 7 shows that strike breakers were less likely to be used, and the fraction replaced was lower given the presence of strike breakers, in firms with a high fraction of female employees. Since female workers were paid less, were less likely to be organized, and were perhaps more easily replaced, these findings support Freeman's hypothesis. ${ }^{22}$

Finally, in view of the importance that has been attached to the use of the injunction by authors such as Hattam [1993] who argues that the labor movement lobbied more than forty years for limitations on the use of the injunctions, it is remarkable that we do not find any significant effect of the injunction on strike outcomes. Obviously, injunctions were used to alter strike outcomes in specific cases. But our results suggest

22 Just as unions advocated at least some laws against intimidation and boycotts (perhaps to reduce the uncertainty that resulted when such matters were left up to judges interpreting the common law), employers may have advocated anti-blacklist laws for the same reasons. This might account for the anti-labor results of these laws, but not for labor's willingness to support them: the fourth change noted by Hattam [1993, p. 144] in New York's conspiracy laws (in 1887) was actually a change to allow prosecution of employers who blacklisted workers joining unions:

Any person or persons, employer or employers of labor, and any person or persons of any corporation or corporations on behalf of such corporation or corporations, who shall hereafter coerce or compel any person or persons, employe or employes [sic], laborer or mechanic, to enter into an agreement, either written or verbal, from such person, persons, laborer, or mechanic, not to join or become a member of any labor organization, as a condition of such person or persons securing employment or continuing in the employment of any such person or persons, employer or employers, corporation or corporations, shall be deemed guilty of a misdemeanor [Laws of the State of New York, Chap. 688, p. 897, June 24, 1887].

The support of New York's Workingmen's Assembly for this legislation suggests that labor expected that it would produce favorable outcomes in disputes with employers. 
that the mere threat that an injunction could be imposed had little effect on outcomes, at least when year effects are included in the model. ${ }^{23}$

The lack of an effect of the use of the injunction on strike outcomes cannot be explained by selection. We saw above that the use of the injunction had no effect on aggregate strike incidence, although strikes in jurisdictions that had used the injunction were less likely to be union authorized, and had a higher fraction of female workers involved. These findings suggest that, if anything, changes in the sample composition associated with the use of the injunction would bias our results towards finding excessively negative outcomes for labor.

When we factor in the additional strike costs incurred by workers and firms in jurisdictions where the injunction had been used, we are left with a final puzzle: why were employers increasingly enamored of an anti-labor device that brought them no tangible benefits, while imposing significant costs?

\section{Conclusions}

Our results demonstrate that labor's attempts to achieve its goals through the enactment of pro-labor legislation had some significant effects on the success of organizing activity as measured by strike costs and strike outcomes. However, the effects were not always in the anticipated directions, and some of the most hard-won legislative victories proved relatively ineffective. On the whole, then, our results are consistent with the spirit of Hattam's [1993] argument, and suggest that the American labor movement may have turned to business unionism because it found the law to be an inaccurate instrument for changing the balance of power in the labor market.

${ }^{23}$ It is possible, for example, that it was the first injunction used anywhere in the U.S. that established a "threat" and altered strike outcomes. In this case, the effect of the injunction would be absorbed by the year effect in our regressions. 
We find, for example, that laws legalizing unions had little impact on employment, wage or hours changes, the use of strike breakers, or strike costs. Pro-labor anti-blacklist laws had the paradoxical effect of increasing employer resistance, as evidenced by an increase in the use of strike replacements. Maximum hours laws were the only laws that were unambiguously pro-labor in their effects since they were associated with higher wage increases, reduced strike costs, and reduced use of strike replacements. However, some of this effect could be due to changes in the composition of the sample of strikes that accompanied the passage of maximum hours laws. Finally, though labor feared the increasing use of the injunction, we are unable to detect any "threat" effect associated with past use of the injunction in a given state. In fact, between 1881 and 1894, the use of the injunction imposed costs on both workers and employers by lengthening strikes without providing any substantial benefits to the employers who sought them.

\section{References}

Atack, Jeremy, and Fred Bateman, State Sample from the 1880 Census of Manufacturing. ICPSR 9384 (Ann Arbor, MI: Inter-University Consortium for Political and Social Research, 1990).

Bailey, Gary L., "The Commissioner of Labor's Strikes and Lockouts: A Cautionary Note," Labor History, XXXII (1991), 432-40.

Card, David and Craig Olson, "Bargaining Power, Strike Duration, and Wage Outcomes: An Analysis of Strikes in the 1880s," National Bureau of Economic Research Working Paper No. 4075, 1992.

Chandler, Alfred D., The Visible Hand: The Managerial Revolution in American Business (Cambridge: Harvard University Press, 1977).

Commons, John R, and John B. Andrews, Principles of Labor Legislation (New York: Macmillan, 1927).

Commons, John R., David J. Saposs, Helen L. Sumner, E.B. Mittelman, H.E. Hoagland, John B. Andrews, and Selig Perlman, History of Labour in the United States (New York: Macmillan, 1918-1926).

Currie, Janet and Sheena McConnell, "The Impact of Collective Bargaining Legislation on Disputes in the U.S. Public Sector: No Policy May be the Worst Policy," National Bureau of Economic Research Working Paper No. 3978, 1992.

Edwards, P.K., Strikes in the United States, 1881-1974 (Oxford: Basil Blackwell, 1981). 
Farber, Henry S., "The Analysis of Union Behavior," in Handbook of Labor Economics, Orley Ashenfelter and Richard Layard, eds. (New York: Elsevier, 1986).

Frankfurter, Felix, and Nathan Greene, The Labor Injunction (New York: Macmillan, 1930).

Freeman, Richard, "Contraction and Expansion: The Divergence of Private Sector and Public Sector Unionism in the United States," Journal of Economic Perspectives, II (1988), 63-88.

Freeman, Richard, "On the Divergence of Unionism Among Developed Countries," National Bureau of Economic Research Working Paper No. 2817, 1989.

Friedman, Gerald, "Politics and Unions,” Ph.D. thesis, Harvard University, 1986.

Friedman, Lawrence M., A History of American Law (New York: Simon and Schuster, 1973).

Goldin, Claudia D., "Maximum Hours Legislation and Female Employment in the 1920s: A Reassessment," Journal of Political Economy, XCVI (1988), 189-205.

Griffen, J.I., Strikes: A Study in Quantitative Economics (New York: Columbia University Press, 1939).

Hattam, Victoria, Labor Visions and State Power (Princeton: Princeton University Press, 1993).

Heckman, James and Brooks Paynor, "Determining the Impact of Federal Anti-discrimination Policy on the Economic Status of Blacks: A Study of South Carolina," American Economic Review, DXXIX (1989), 138-77.

Hughes, Jonathan R.T., Social Control in the Colonial Economy (Charlottesville: University of Virginia Press, 1976).

Kennan, John, "The Economics of Strikes," in Handbook of Labor Economics, Orley Ashenfelter and Richard Layard, eds. (New York: Elsevier, 1986).

Lebergott, Stanley, "The American Labor Force," in American Economic Growth, Lance Davis et al., eds. (New York: Harper and Row, 1972).

Lewis, H. Gregg, Union Relative Wage Effects: A Survey (Chicago: University of Chicago Press, 1986).

Oakes, Edwin Stacey, The Law of Organized Labor and Industrial Conflicts (Rochester: The Lawyers Cooperative Publishing Company, 1927).

Petro, Sylvester, "Assumptions and Premises of National Labor Policy: 1,032 Points of Light on the Subject," Wake Forest Law Review, XXVI (1991), 965-1184.

Rees, Albert, The Economics of Trade Unions (Chicago: University of Chicago Press, 1977).

Stimson, F.J., Handbook to the Labor Law of the United States (New York: Scribners, 1896). 
Tomlins, Christopher L., The State and the Unions: Labor Relations, Law, and the Organized Labor Movement in America, 1880-1960 (New York: Cambridge University Press, 1985).

U.S. Census Office, Eleventh Census of the United States, 1890: Vol. XI-XIII, Report on Manufacturing Industries in the United States at the Eleventh Census (Washington, DC: Government Printing Office, 1892-1897).

U.S. Bureau of the Census, Twelfth Census of the United States, 1900: Vol. VII-X, Manufacturers (Washington, DC: Government Printing Office, 1902).

U.S. Bureau of the Census, Historical Statistics of the United States, Colonial Times to 1970 (Washington, DC: Government Printing Office, 1975).

U.S. Commissioner of Labor, Third Annual Report (Washington, DC: Government Printing Office, 1888).

U.S. Commissioner of Labor, Tenth Annual Report (Washington, DC: Government Printing Office, 1896).

Witte, Edwin E., “Early American Labor Cases,” Yale Law Journal, XXXV (1926), 825-37.

Zucker, Lynne G, Kam-bor Yip, and Matthijs Kalmijn, "Strikes as Institution-Building: Union Locals as Strike Outcomes and Strike Moderators in the 1880s," in Studies in Labor Markets and Institutions, Kenneth L. Sokoloff, ed. (Los Angeles: Institute of Industrial Relations, University of California, Los Angeles, 1992).

\section{Data Appendix: \\ Sources for State Laws Dealing With Labor and Strikes}

Connecticut

Maximum Hours General Statutes of Connecticut: Revised 1875, Title 14, Chap. 106, \$10, p. 194 (Hartford: Case, Lockwood, and Brainard, 1875).

Intimidation Public Acts Passed By the General Assembly of the State of Connecticut in the Year 1878, Chap. 92, §2, p. 315 (Hartford: Case, Lockwood, and Brainard, 1878).

Boycotts Public Acts Passed By the General Assembly of the State of Connecticut in the Year 1878, Chap. 92, \$2, p. 315 (Hartford: Case, Lockwood, and Brainard, 1878).

Blacklist Public Acts Passed By the General Assembly of the State of Connecticut in the Year 1897, Chap. 184, p. 881 (Hartford: Case, Lockwood, and Brainard, 1897).

\section{Delaware}

None

Ilinols

Maximum Hours Public Laws of the State of Illinois Passed By the Twenty Fifth General Assembly, Convened January Seventh, 1867, §1-2, pp. $101-2$ (Springfield: Baker, Bailache and Co., 1867). 
Intimidation

Boycotts

Blacklists

Injunction

\section{Indiana}

Unions Legal

Maximum Hours

Intimidation

Blacklists

Injunction

Maine

Maximum Hours

Intimidation

Boycotts

\section{Maryland}

Unions Legal

Laws of the State of Maryland Made and Passed at a Session of the General Assembly Begun and Held at the City of Annapolis on the Second Day of Jamuary, 1884, and Ended on the Thirty First Day of March, 1884, Chap. 267-267, pp. 366-77 (Annapolis: James Young, 1884)

Maximum Hours Laws of the State of Maryland Made and Passed at a Session of the General Assembly Begun and Held at the City of Annapolis on the Sixth Day of January, 1886, and Ended on the Fifth

Day of April, 1886, Chap. 163, pp. 276-7 (Baltimore: John Murphy, 1886).

Public Laws of the State of Illinois Passed By the Twenty Third General Assembly, Convened January Fifth, $1863, \S 1$, p. 70 (Springfield: Baker and Phillips, 1863).

Laws of the State of Illinois Enacted By the Thirty Fifth General Assembly At the Session Which Commenced January Fifth, 1887 and Adjoumed June Fifteenth, 1887, \$1, pp. 167-8 (Springfield: H.W. Rokker, 1887).

Laws of the State of Illinois Enacted By the Thirty Fifth General Assembly At the Session Which Commenced January Fifth, 1887 and Adjoumed June Fifteenth, 1887, \$1, pp. 167-168 (Springfield: H.W. Rokker, 1887).

Bruschke v. Furniture Workers' Union No. 1 (18 Chi. L. News, 306); cited in Witte [1926, p. 833, note 36].

Laws of the State of Indiana Passed at the Fifty Eighth Regular Session of the General Assembly Begun on the Fifth Day of January, A.D. 1893, Chap. 76, p. 146 (Indianapolis: Wm. B. Burford, 1893).

Begun on the Tenth Day of January, A.D. 1889, Chap. 80, p. 143 (Indianapolis: Wm. B. Burford, 1889).

Laws of the State of Indiana Passed at the Fifty Second Regular Session of the General Assembly Begun on the Sixth Day of January, A.D. 1881, Chap. 30, \$216, p. 221 (Indianapolis: Carlon and Hollenbeck, 1881); repealed, Laws of the State of Indiana Passed at the Fifty Sixth Regular Session of the General Assembly Begun on the Tenth Day of January, A.D. 1889, Chap. 181, p. 339 (Indianapolis: Wm. B. Burford, 1889).

Laws of the State of Indiana Passed at the Fifty Sixth Regular Session of the General Assembly Begun on the Tenth Day of January, A.D. 1889, Chap. 166, p. 315 (Indianapolis: Wm. B. Burford, 1889).

Lake Erie \& W. Ry. v. Bailey (61 F. 494, C.C.E.D. Ind., 1893); cited in Petro [1991, p. 1026]. Acts and Resolves of the Sixty Forth Legislature of the State of Maine, Chap. 303, p. 267 (Augusta: Burleigh and Flynt, 1889).

Acts and Resolves of the Sixty Forth Legislature of the State of Maine, Chap. 303, p. 267 (Augusta: Burleigh and Flynt, 1889). 


\section{Massachusetts}

Unions Legal Acts and Resalves Passed By the General Court of Massachusetts in the Year 1888, Chap. 134, pp. 99-100 (Boston: Wright and Potter, 1888).

Maximum Hours Acts and Resolves Passed By the General Court of Massachusetts in the Year 1890, Chap. 375, p. 339 (Boston: Wright and Potter, 1890).

Intimidation Acts and Resolves Passed By the General Court of Massachusetts in the Year 1875, Chap. 211, pp. 833-4 (Boston: Wright and Potter, 1875).

Blacklists Acts and Resolves Passed By the General Court of Massachusetts in the Year 1892, Chap. 330, p. 315 (Boston: Wright and Potter, 1892).

Injunction

Sherry v. Perkins (147 Mass. 212, 214); cited in Frankfurter and Greene [1930, p. 22, note 95] and Oakes [1927, p. 454, note 52].

\section{Michigan}

Unions Legal

Public Acts and Joint Concurrent Resolutions of the Legislature of the State of Michigan Passed at the Regular Session of 1883, No. 159, pp. $171-3$ (Lansing: W.S. George and Co., 1883).

Maximum Hours Public Acts and Joint Concurrent Resolutions of the Legislature of the State of Michigan Passed at the Regular Session of 1885, No. 137, pp. 154-5 (Lansing: W.S. George and Co., 1885).

Intimidation

Acts of the Legislature of the State of Michigan Passed at the Regular Session of 1867, Vol. I, No. 163, pp. 218-9 (Lansing: John A. Kerr and Co., 1867).

Injunction

Beck v. Railway Teamsters' Protective Union (118 Mich. 497); cited in Frankfurter and Greene $[1930$, p. 24, note 101] and Oakes [1927, pp. 888-9, note 71].

\section{New Hampshire}

Maximum Hours

Laws of the State of New Hampshire Pas (Concord: Butterfield and Hill, 1847).

Intimidation Laws of the State of New Hampshire Passed June Session, 1887, Chap. 54, p. 441 (Concord: Josiah B. Sanborn, 1887).

Boycotts Laws of the State of New Hampshire Passed June Session, 1887, Chap. 54, p. 441 (Concord: Josiah B. Senborn, 1887).

\section{New Jersey}
Unions Legal
Acts of the One Hundred and First Legislature of the State of New Jersey: 1877, Chap. 89, p. 142-143 (Mount Holly: William B. Willis, 1877).
Maximum Hours Acts of the One Hundred and Eleventh Legislature of the State of New Jersey: 1887, Chap. 108 , pp. 145-6 (Camden: The Courier Publishing Association, 1887)
Injunction
Bart v. Essex Trades Council (53 N.J. Eq. 101, 30 Atl. 881); cited in Oakes [1927, pp. 869-70, note 4] and Frankfurter and Greene [1930, p. 24, note 101] 
New York

Unions Legal Laws of the State of New York Passed At the Ninety Third Session of the Legislature Begun January Fourth, 1870, and Ended April Twenty Sixth, 1870, in the City of Albary, Vol. I, Chap. 19, p. 30 (Albany: Weed, Parsons and Co., 1870).

Maximum Hours Laws of the State of New York Passed At the Ninety Third Session of the Legislature Begun January Fourth, 1870, and Ended April Twenty Sixth, 1870, in the City of Albamy, Vol. I, Chap. 385, pp. 919-20 (Albany: Weed, Parsons and Co., 1870).

Intimidation Laws of the State of New York Passed At the One Hundred and Fifth Session of the Legislature Begun January Third, 1882, and Ended June Second, 1882, in the City of Albamy, Chap. 384, $\$ 653$, p. 545 (Albany: Weed, Parsons and Co., 1882).

Boycotts Laws of the State of New York Passed At the One Hundred and Fifth Session of the Legislature Begun January Third, 1882, and Ended June Second, 1882, in the City of Albany, Chap. 384, $\$ 675$, p. 545 (Albany: Weed, Parsons and Co., 1882).

Blacklists Laws of the State of New York Passed At the One Hundred and Tenth Session of the Legislature Begun January Fourth, 1887, and Ended May Twenty Sixth, 1887, in the City of Albany, Chap. 688, p. 897 (Albany: Banks and Brothers, 1887).

Injunction Davis v. Zimmerman (91 Hun. 489, 36 N.Y.S. 303); cited in Petro [1991, p. 1063].

Ohio

Unions Legal General and Local Acts Passed and Joint Resolutions Adopted By the Seventieth General Assembly At Its Adjoumed Session Begun and Held in the City of Columbus, January Thirteenth, 1892, No. 295, p. 269 (Columbus: Myers Brothers, 1892).

Maximum Hours General and Local Laws and Joint Resolutions Passed By the Sixty Seventh General Assembly At Its Adjourned Session Begun and Held in the City of Columbus, January Fourth, 1886, No. 65, pp. 76-7 (Columbus: Myers Brothers, 1886)

Injunction N.Y. Lake Erie RR v. Wenger; cited in Petro [1991, p. 1100].

\section{Pennsylvania}

Unions Legal Laws of the General Assembly of the State of Pennsyluania Passed at the Session of 1869 In the Ninety Third Year of Independence With An Appendix, No. 1242, pp. 1260-1 (Harrisburg: B. Singerly, 1869).

Maximum Hours Laws of the General Assembly of the State of Pennsylvania Passed at the Session of 1887 In the One Hundred and Eleventh Year of Independence, No. 10, pp. 13-4 (Harrisburg: Edwin K. Meyers, 1887).

Blacklists Laws of the General Assembly of the State of Pennsyluania Passed at the Session of 1897 In the One Hundred and Twenty First Year of Independence, No. 98, p. 116 (Harrisburg: Clarence M. Busch, 1897).

Injunction Brace Bros. v. Evans (5 Pa. Co. Ct. 163); cited in Witte [1926, p. 833, note 40], Oakes [1927, p. 156 , note 45$]$, and Frankfurter and Greene [1930, p. 22]. 
TABLE 1

Date of Passage of State Laws Dealing With Labor and Strikes

$1880-1900$

\begin{tabular}{|c|c|c|c|c|c|c|}
\hline State & $\begin{array}{l}\text { Unions } \\
\text { Legal" }\end{array}$ & $\begin{array}{c}\text { Maximum } \\
\text { Hours }^{b}\end{array}$ & $\begin{array}{l}\text { Intimidation } \\
\text { Illegal }^{c}\end{array}$ & $\begin{array}{l}\text { Boycotts } \\
\text { [llegal }^{d}\end{array}$ & $\begin{array}{c}\text { Blacklists } \\
\text { Illegal }\end{array}$ & $\begin{array}{l}\text { Injunction } \\
\text { Used }^{\text {Un }}\end{array}$ \\
\hline Connecticut & no law & $1 / 1 / 1867$ & $3 / 29 / 1878$ & $3 / 29 / 1878$ & $4 / 25 / 1897$ & no \\
\hline Delaware & no law & no law & no law & no law & no law & no \\
\hline Illinois & no law & $5 / 1 / 1867$ & $2 / 13 / 1863$ & $7 / 1 / 1887$ & $7 / 1 / 1887$ & 1886 \\
\hline Indiana & $2 / 25 / 1893$ & $5 / 10 / 1889$ & $4 / 14 / 1881^{f}$ & no law & $3 / 9 / 1889$ & 1893 \\
\hline Maine & no law & $1 / 1 / 1871$ & $3 / 13 / 1889$ & $3 / 13 / 1889$ & no law & no \\
\hline Maryland & $4 / 8 / 1884$ & $4 / 1 / 1886$ & no law & no law & no law & no \\
\hline Massachusetts & $3 / 14 / 1888$ & $5 / 3 / 1890$ & $5 / 14 / 1875$ & no law & $5 / 31 / 1892$ & 1888 \\
\hline Michigan & $6 / 6 / 1883$ & $6 / 5 / 1885$ & $3 / 27 / 1867$ & no law & no law & 1898 \\
\hline New Hampshire & no law & $7 / 3 / 1847$ & $9 / 29 / 1887$ & $9 / 29 / 1887$ & no law & no \\
\hline New Jersey & $3 / 9 / 1877$ & $4 / 8 / 1887$ & no law & no law & no law & 1894 \\
\hline New York & $2 / 17 / 1870$ & $4 / 26 / 1870$ & $6 / 30 / 1882$ & $6 / 30 / 1882$ & $6 / 24 / 1887$ & 1895 \\
\hline Ohio & $4 / 14 / 1892$ & $5 / 1 / 1886$ & no law & no law & no law & 1887 \\
\hline Pennsylvania & $5 / 8 / 1869$ & $3 / 24 / 1887$ & no law & no law & $6 / 4 / 1897$ & 1888 \\
\hline
\end{tabular}

Notes: 'Laws declaring that collective action to raise wages was not an actionable conspiracy, or laws preventing the discharge of workers because of union membership, or laws establishing procedures for unions to incorporate.

'Laws specifying the maximum length of the workday either in the absence of any specific agreement to the contrary, or in specific industries, or in the employment of the state.

' Laws preventing the use of threats or force to prevent workers from practicing their trade.

"Anti-intimidation laws that were written to include the intimidation of customers, anti-conspiracy laws that were written to prevent collective action that was directed at preventing trade or business, or laws that specifically outlawed boycotts.

- The earliest year for which a citation could be found in Frankfurter and Greene [1930], Oakes [1927], Petro [1991], or Witte [1926]

to indicate that an injunction had been issued and sustained by a federal or state court in a labor dispute.

${ }^{i}$ Repealed 3/9/1889.

Source: See the Data Appendix. 
TABLE 2

Strike Characteristics in Each State, Year, and Industry

\begin{tabular}{|c|c|c|c|c|c|c|c|c|c|c|c|c|}
\hline & $\begin{array}{c}\% \text { Strike } \\
\text { Authorized }\end{array}$ & $\begin{array}{c}\text { (2) } \\
\text { Mean } \\
\text { Emp. } \\
\text { before } \\
\text { Strike }\end{array}$ & $\begin{array}{c}\text { (3) } \\
\text { Fraction } \\
\text { Using } \\
\text { Strike } \\
\text { Breakers }\end{array}$ & $\begin{array}{c}\text { (4) } \\
\text { Fraction } \\
\text { Rep. } \\
\text { if Rep. } \\
\text { Used }\end{array}$ & $\begin{array}{c}\text { (5) } \\
\text { Mean } \\
\text { Fraction } \\
\text { Rep. }\end{array}$ & $\begin{array}{l}\text { (6) } \\
\text { Mean } \\
\% \text { Ch. } \\
\text { Emp. }\end{array}$ & $\begin{array}{c}\text { (7) } \\
\text { Mean } \\
\text { Hours } \\
\text { before } \\
\text { strike }\end{array}$ & $\begin{array}{c}\text { (8) } \\
\text { Mean } \\
\% \text { Ch. } \\
\text { Hours }\end{array}$ & $\begin{array}{c}\text { (9) } \\
\text { Mean } \\
\text { Wage } \\
\text { before } \\
\text { strike }\end{array}$ & $\begin{array}{l}\text { (10) } \\
\text { Mean } \\
\% \mathrm{Ch} . \\
\text { Wage }\end{array}$ & $\begin{array}{c}\text { (I1) } \\
\text { Median } \\
\text { Strike } \\
\text { Duration }\end{array}$ & $\begin{array}{c}\text { Median } \\
\text { Days } \\
\text { Lost }\end{array}$ \\
\hline $\begin{array}{l}\text { All Strikes } \\
\text { By State }\end{array}$ & .65 & 387 & .42 & .25 & .11 & -1.60 & 58 & -.61 & 1.91 & 2.27 & 7 & 765 \\
\hline Connecticut (517) & .34 & 283 & .43 & .19 & .08 & -.05 & 60 & -.44 & 1.51 & 1.27 & 5 & 735 \\
\hline Delaware (39) & .62 & 268 & .62 & .31 & .19 & -20.66 & 57 & -2.46 & 1.61 & -8.03 & 17 & 2635 \\
\hline Illinois (1587) & .68 & 743 & .40 & .28 & .11 & -.40 & 59 & -1.46 & 2.00 & 1.60 & 7 & 990 \\
\hline Indiana (308) & .60 & 408 & .33 & .28 & .09 & -2.89 & 59 & -.71 & 1.78 & 1.01 & 7 & 888 \\
\hline Massachusetts (2392) & .56 & 336 & .47 & .20 & .10 & -2.90 & 59 & -.27 & 1.74 & 2.90 & 7 & 852 \\
\hline Maryland (164) & .73 & 308 & .49 & .25 & .12 & -3.02 & 59 & -.35 & 1.67 & 1.52 & 10 & 1175 \\
\hline Maine (119) & .58 & 360 & .46 & .19 & .08 & -5.48 & 60 & -.67 & 1.61 & 2.58 & 8 & 1575 \\
\hline Michigan (273) & .55 & 297 & .49 & .30 & .15 & -2.51 & 59 & -.74 & 1.71 & 1.82 & 10 & 1000 \\
\hline New Hampshire (85) & .46 & 314 & .35 & .20 & .07 & -4.74 & 59 & -.77 & 1.66 & 1.24 & 9 & 1470 \\
\hline New Jersey (490) & .68 & 304 & .43 & .26 & .11 & -5.39 & 58 & -.71 & 1.91 & 2.23 & 7 & 873 \\
\hline New York (3962) & .83 & 190 & .38 & .28 & .13 & -.66 & 57 & -.64 & 2.21 & 5.62 & 6 & 256 \\
\hline Ohio (1075) & .57 & 327 & .39 & .22 & .09 & -4.14 & 59 & -.44 & 1.77 & .72 & 12 & 1314 \\
\hline Pennsylvania (1954) & .52 & 664 & .43 & .22 & .10 & -.76 & 59 & -.33 & 1.76 & .59 & 11 & 2000 \\
\hline \multicolumn{13}{|l|}{ By Year } \\
\hline $1881(500)$ & .53 & 268 & .38 & .28 & .11 & -.65 & 63 & -1.04 & 1.89 & 5.40 & 7 & 990 \\
\hline $1882(433)$ & .55 & 371 & .36 & .27 & .10 & -.56 & 60 & -.19 & 2.01 & 3.37 & 7 & 1137 \\
\hline $1883(464)$ & .61 & 308 & .43 & .29 & .12 & -2.35 & 58 & -.02 & 1.92 & 2.16 & 10 & 1000 \\
\hline $1884(418)$ & .60 & 347 & .42 & .27 & .11 & -3.52 & 60 & -1.16 & 2.04 & -1.65 & 11 & 1014 \\
\hline $1885(616)$ & .57 & 392 & .39 & .28 & .11 & -2.87 & 59 & -.14 & 1.83 & 1.58 & 14 & 1694 \\
\hline $1886(1856)$ & .66 & 310 & .42 & .28 & .12 & -1.05 & 60 & -1.69 & 1.88 & 2.29 & 11 & 1035 \\
\hline $1887(1348)$ & .63 & 420 & .45 & .24 & .13 & . & 59 & -.43 & . & . & 6 & 700 \\
\hline $1888(802)$ & .68 & 376 & .44 & .25 & .13 & . & 59 & -.26 & 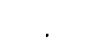 & . & 7 & 720 \\
\hline $1889(921)$ & .67 & 454 & .43 & .23 & .12 & . & 59 & -.49 & . & . & 6 & 644 \\
\hline $1890(893)$ & .61 & 457 & .40 & .22 & .09 & . & 59 & -.92 & 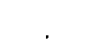 & . & 7 & 900 \\
\hline $1891(1509)$ & .73 & 287 & .39 & .25 & .10 & . & 57 & -.50 & . & . & 6 & 483 \\
\hline $1892(1173)$ & .69 & 295 & .41 & .23 & .09 & . & 56 & -.30 & . & . & 6 & 525 \\
\hline $1893(1145)$ & .68 & 403 & .46 & .23 & .11 & . & 57 & -.30 & . & . & 7 & 560 \\
\hline $1894(803)$ & .63 & 805 & .40 & .20 & .09 & . & 57 & -.06 & & . & 7 & 725 \\
\hline
\end{tabular}


TABLR 2

(Continued)

Strike Characteristics in Each State, Year, and Industry

\begin{tabular}{|c|c|c|c|c|c|c|c|c|c|c|c|c|}
\hline & $\begin{array}{c}\% \text { Strike } \\
\text { Authorized }\end{array}$ & $\begin{array}{c}\text { (2) } \\
\text { Mean } \\
\text { Emp. } \\
\text { before } \\
\text { Strike }\end{array}$ & $\begin{array}{c}(3) \\
\text { Fraction } \\
\text { Using } \\
\text { Strike } \\
\text { Breakers }\end{array}$ & $\begin{array}{c}\text { (4) } \\
\text { Fraction } \\
\text { Rep. } \\
\text { if Rep. } \\
\text { Used }\end{array}$ & $\begin{array}{c}\text { (5) } \\
\text { Mean } \\
\text { Fraction } \\
\text { Rep. }\end{array}$ & $\begin{array}{l}\text { (6) } \\
\text { Mean } \\
\% \mathrm{Ch} . \\
\text { Emp. }\end{array}$ & $\begin{array}{c}(7) \\
\text { Mean } \\
\text { Hours } \\
\text { before } \\
\text { strike }\end{array}$ & $\begin{array}{l}\text { (8) } \\
\text { Mean } \\
\% \text { Ch. } \\
\text { Hours }\end{array}$ & $\begin{array}{c}(9) \\
\text { Mean } \\
\text { Wage } \\
\text { before } \\
\text { strike }\end{array}$ & $\begin{array}{l}\text { (10) } \\
\text { Mean } \\
\% \mathrm{Ch} . \\
\text { Wage } \\
\end{array}$ & $\begin{array}{c}\text { (11) } \\
\text { Median } \\
\text { Strike } \\
\text { Duration }\end{array}$ & $\begin{array}{c}\text { (12) } \\
\text { Median } \\
\text { Days } \\
\text { Lost }\end{array}$ \\
\hline \multicolumn{13}{|l|}{ By Industry } \\
\hline $1(2888)$ & .63 & 330 & .40 & .18 & .08 & -2.70 & 60 & -.13 & 1.60 & 2.81 & 7 & 980 \\
\hline $2(944)$ & .46 & 374 & .51 & .26 & .13 & -1.95 & 61 & -.64 & 1.63 & 2.35 & 7 & 780 \\
\hline $3(802)$ & .78 & 206 & .43 & .27 & .12 & -1.16 & 59 & -1.37 & 1.92 & 1.31 & 10 & 630 \\
\hline $4(234)$ & .86 & 586 & .57 & .30 & .18 & -.86 & 72 & -4.00 & 1.96 & 7.50 & 4 & 190 \\
\hline $5(1084)$ & .50 & 822 & .31 & .21 & .07 & -2.91 & 58 & -.36 & 1.78 & -1.96 & 14 & 3150 \\
\hline $6(275)$ & .64 & 385 & .47 & .18 & .09 & -1.60 & 59 & -.57 & 2.16 & 2.23 & 12 & 1350 \\
\hline $7(1376)$ & .55 & 458 & .44 & .20 & .09 & -.54 & 60 & -.34 & 1.94 & 1.37 & 10 & 1600 \\
\hline $8(331)$ & .76 & 167 & .67 & .32 & .23 & -3.95 & 58 & -.22 & 2.16 & 3.94 & 6 & 300 \\
\hline $9(255)$ & .19 & 266 & .49 & .37 & .19 & 7.29 & 59 & -.69 & 1.51 & 2.30 & 3 & 325 \\
\hline $10(614)$ & .35 & 1088 & .56 & .26 & .14 & .67 & 65 & -.42 & 1.96 & 5.98 & 3 & 588 \\
\hline $11(2560)$ & .84 & 250 & .34 & .28 & .11 & -.94 & 54 & -.94 & 2.64 & 4.89 & 5 & 228 \\
\hline $12(256)$ & .62 & 315 & .38 & .17 & .06 & -.83 & 56 & -.11 & 2.11 & -.80 & 14 & 2390 \\
\hline $13(502)$ & .73 & 153 & .42 & .28 & .12 & .21 & 55 & -1.09 & 2.28 & 2.09 & 7 & 366 \\
\hline $14(760)$ & .87 & 189 & .41 & .36 & .15 & -3.50 & 54 &. .47 & 1.67 & 4.11 & 14 & 600 \\
\hline
\end{tabular}

Notes: $\quad$ Numbers of strikes in parentheses. The fraction replaced is conditional on strike replacements being used. Employment and wage data (columns 2, 6, 9, and 10) are available only for 1881 to 1886 . The industry codes are as follows: 1=clothing, textiles and shoes, $2=$ miscellanoous, $3=$ cooperage, wooden goods and furniture, 4=food preparation and brewing, 5=mining industry, 6=machines and machinery industries, 7=metals and metallic goods, 8=printing publishing, and telegraph, 9-public way or works constructions, 10-transportation industry, $11=$ building trades including construction of carriages and transportation equipment, 12=glass and pottery, 13=stone quarrying and cutting, and

14=tobacco.

Source: U.S. Commissioner of Labor [1888] and U.S. Commissioner of Labor [1896]. 
TABLE 3

Mean Strike Characteristics and Outcomes By Legal Environment

\begin{tabular}{|c|c|c|c|c|c|c|c|c|c|c|c|c|}
\hline & $\begin{array}{c}\% \text { Strike } \\
\text { Authorized }\end{array}$ & $\begin{array}{c}\text { (2) } \\
\text { Mean } \\
\text { Emp. } \\
\text { before } \\
\text { Strike }\end{array}$ & $\begin{array}{c}\text { (3) } \\
\text { Fraction } \\
\text { Using } \\
\text { Strike } \\
\text { Breakers }\end{array}$ & $\begin{array}{c}\text { (4) } \\
\text { Fraction } \\
\text { Rep. } \\
\text { if Rep. } \\
\text { Used }\end{array}$ & $\begin{array}{c}\text { (5) } \\
\text { Mean } \\
\text { Fraction } \\
\text { Rep. }\end{array}$ & $\begin{array}{c}\text { (6) } \\
\text { Mean } \\
\% \text { Ch. } \\
\text { Emp. }\end{array}$ & $\begin{array}{c}(7) \\
\text { Mean } \\
\text { Hours } \\
\text { before } \\
\text { strike }\end{array}$ & $\begin{array}{l}\text { (8) } \\
\text { Mean } \\
\% \text { Ch. } \\
\text { Hours }\end{array}$ & $\begin{array}{c}\text { (9) } \\
\text { Mean } \\
\text { Wage } \\
\text { before } \\
\text { strike }\end{array}$ & $\begin{array}{l}(10) \\
\text { Mean } \\
\% \mathrm{Ch} . \\
\text { Wage }\end{array}$ & $\begin{array}{c}\text { (11) } \\
\text { Median } \\
\text { Duration } \\
\text { Strike }\end{array}$ & $\begin{array}{c}\text { (12) } \\
\text { Median } \\
\text { Days } \\
\text { Lost }\end{array}$ \\
\hline All Strikes & .65 & 387 & .42 & .25 & .11 & -1.60 & 58 & -.61 & 1.91 & 2.27 & 7 & 765 \\
\hline \multicolumn{13}{|l|}{ Unions Legal } \\
\hline Yes (9102) & .68 & 343 & .43 & .25 & .11 & -1.15 & 58 & -.48 & 1.99 & 3.10 & 7 & 630 \\
\hline No (4288) & .58 & 478 & .40 & .25 & .10 & -2.10 & 59 & -.89 & 1.82 & 1.38 & 7 & 1098 \\
\hline \multicolumn{13}{|c|}{ Maximum Hours Leg. } \\
\hline Yes (9127) & .70 & 407 & .41 & .26 & .11 & -.82 & 58 & -.73 & 2.02 & 3.44 & 7 & 616 \\
\hline No (4263) & .54 & 344 & .44 & .22 & .10 & -2.59 & 59 & -.36 & 1.77 & .82 & 7 & 1190 \\
\hline \multicolumn{13}{|c|}{ Intimidation/Boycotts } \\
\hline Yes (9334) & .68 & 341 & .41 & .25 & .11 & -1.07 & 58 & -.67 & 1.99 & 2.80 & 7 & 566 \\
\hline No (4056) & .57 & 490 & .43 & .23 & .10 & -2.33 & 59 & -.48 & 1.80 & 1.56 & 10 & 1500 \\
\hline \multicolumn{13}{|c|}{ Blacklists Illegal } \\
\hline Yes (3009) & .77 & 254 & .39 & .25 & .11 & $\ldots$ & 56 & -.32 & $\ldots$ & $\ldots$ & 5 & 270 \\
\hline No (9648) & .61 & 436 & .43 & .25 & .11 & -1.60 & 59 & -.72 & $\ldots$ & $\ldots$ & 7 & 1050 \\
\hline \multicolumn{13}{|c|}{ Injunction Used } \\
\hline Yes (3358) & .58 & 478 & .47 & .21 & .10 & $\ldots$ & 58 & -.32 & $\ldots$ & $\ldots$ & 7 & 1050 \\
\hline No (9607) & .67 & 355 & .40 & .26 & .11 & -1.60 & 58 & -.71 & 1.91 & 2.27 & 7 & 686 \\
\hline
\end{tabular}

Notes: Number of strikes in parentheses. Columns 2,6,9, and 10 use 1881-1886 only.

Source: $\quad$ See Table 2. 
TABLE 4

The Effects of the Law on Aggregate Strike Activity

\begin{tabular}{|c|c|c|c|}
\hline Dependent Variable: & $\begin{array}{c}\text { (1) } \\
\text { \# Strikes }\end{array}$ & $\begin{array}{c}(2) \\
\text { \# Strikers } \\
(1000 \mathrm{~s})\end{array}$ & $\begin{array}{c}\text { (3) } \\
\text { \# Strike } \\
\text { Days (1000s) }\end{array}$ \\
\hline Intercept & $\begin{array}{r}32.60 \\
(.38)\end{array}$ & $\begin{array}{r}-28.69 \\
(.72)\end{array}$ & $\begin{array}{r}-840.03 \\
(.63)\end{array}$ \\
\hline Unions Legal & $\begin{array}{l}3.76 \\
(.14)\end{array}$ & $\begin{array}{l}5.58 \\
(.46)\end{array}$ & $\begin{array}{r}264.19 \\
\quad(.65)\end{array}$ \\
\hline $\begin{array}{l}\text { Maximum Hours } \\
\text { Legislation }\end{array}$ & $\begin{array}{l}-62.35 \\
(1.94)\end{array}$ & $\begin{array}{r}-20.78 \\
(1.38)\end{array}$ & $\begin{array}{r}-1356.02 \\
(2.69)\end{array}$ \\
\hline $\begin{array}{l}\text { Intimidation/Boycotts } \\
\text { Illegal }\end{array}$ & $\begin{array}{l}27.21 \\
(.76)\end{array}$ & $\begin{array}{l}16.97 \\
(1.01)\end{array}$ & $\begin{array}{r}675.51 \\
(1.20)\end{array}$ \\
\hline Blacklist Illegal & $\begin{array}{r}-32.64 \\
\quad(.96)\end{array}$ & $\begin{array}{l}5.25 \\
(.33)\end{array}$ & $\begin{array}{r}246.22 \\
\quad(.46)\end{array}$ \\
\hline Injunction Used & $\begin{array}{l}19.46 \\
(.59)\end{array}$ & $\begin{array}{l}15.09 \\
(.10)\end{array}$ & $\begin{array}{r}-657.72 \\
(1.27)\end{array}$ \\
\hline $\begin{array}{l}\text { Observations } \\
\mathrm{R}^{2}\end{array}$ & $\begin{array}{l}182 \\
.80\end{array}$ & $\begin{array}{l}182 \\
.74\end{array}$ & $\begin{array}{c}182 \\
.72\end{array}$ \\
\hline $\begin{array}{l}\text { Mean of Dependent } \\
\text { Variable }\end{array}$ & 72.87 & 28.23 & 778.35 \\
\hline
\end{tabular}


TABLe 5

Differences Between Striking Firms and the Average Manufacturing Firm in 1881 and 1891

\begin{tabular}{lccc}
\hline & $(1)$ & $(2)$ & $(3)$ \\
Dependent Variable: & Employment & $\begin{array}{c}\text { Fraction } \\
\text { Female }\end{array}$ & Hours \\
\hline Intercept & 139.54 & -.12 & .92 \\
& $(.89)$ & $(2.05)$ & $(.40)$ \\
Unions Legal & -165.24 & .01 & -2.94 \\
& $(1.40)$ & $(.31)$ & $(1.81)$ \\
Maximum Hours & -37.51 & -.04 & 4.69 \\
Legislation & $(.35)$ & $(.98)$ & $(3.12)$ \\
& & & \\
Intimidation/Boycotts & -306.20 & -.02 & -1.82 \\
Illegal & $(.99)$ & $(.17)$ & $(.48)$ \\
Blacklist Illegal & 50.20 & .13 & -6.85 \\
& $(.16)$ & $(1.16)$ & $(1.71)$ \\
Injunction Used & -18.09 & .07 & -.73 \\
& $(.15)$ & $(1.52)$ & $(.45)$ \\
Observations & 1041 & 1041 & 1192 \\
$\mathrm{R}^{2}$ & .16 & .41 & .57 \\
Mean of Dependent & 243.80 & -.03 & -3.01 \\
Variable & & & \\
\hline Notes: & -statistics in parentheses. All regressions also included state, year, city, and industry dummies.
\end{tabular}


TABLE 6

Union Authorization, Strike Costs, and the Legal Environment

\begin{tabular}{|c|c|c|c|}
\hline Dependent Variable: & $\begin{array}{c}\text { (1) } \\
\text { Union } \\
\text { Authorized }\end{array}$ & $\begin{array}{c}\text { (2) } \\
\text { Log(Strike } \\
\text { Length) }\end{array}$ & $\begin{array}{c}\text { (3) } \\
\text { Log(Strike } \\
\text { Days Lost) }\end{array}$ \\
\hline Intercept & $\begin{array}{c}.63 \\
(7.44)\end{array}$ & $\begin{array}{l}1.90 \\
(7.53)\end{array}$ & $\begin{array}{c}7.56 \\
(19.60)\end{array}$ \\
\hline Unions Legal & $\begin{array}{c}.04 \\
(1.78)\end{array}$ & $\begin{array}{c}.09 \\
(1.18)\end{array}$ & $\begin{array}{l}-.15 \\
(1.35)\end{array}$ \\
\hline $\begin{array}{l}\text { Maximum Hours } \\
\text { Legislation }\end{array}$ & $\begin{array}{l}.01 \\
(.49)\end{array}$ & $\begin{array}{c}-.45 \\
(6.10)\end{array}$ & $\begin{array}{c}-.36 \\
(3.18)\end{array}$ \\
\hline $\begin{array}{l}\text { Intimidation/Boycotts } \\
\text { Illegal }\end{array}$ & $\begin{array}{l}.02 \\
(.52)\end{array}$ & $\begin{array}{c}.14 \\
(1.22)\end{array}$ & $\begin{array}{c}.38 \\
(2.15)\end{array}$ \\
\hline Blacklist Illegal & $\begin{array}{l}.01 \\
(.50)\end{array}$ & $\begin{array}{c}.14 \\
(2.49)\end{array}$ & $\begin{array}{l}-.06 \\
(.68)\end{array}$ \\
\hline Injunction Used & $\begin{array}{c}-.08 \\
(2.89)\end{array}$ & $\begin{array}{c}.21 \\
(2.76)\end{array}$ & $\begin{array}{c}.25 \\
(2.10)\end{array}$ \\
\hline $\begin{array}{l}\text { Log(Pre-strike } \\
\text { Employment) }\end{array}$ & $\begin{array}{l}-.002 \\
(.59)\end{array}$ & $\begin{array}{c}.12 \\
(14.11)\end{array}$ & .. \\
\hline Pre-strike Hours & $\begin{array}{c}-.11 \\
(1.71)\end{array}$ & $\begin{array}{c}-.83 \\
(4.41)\end{array}$ & $\begin{array}{c}-.73 \\
(2.48)\end{array}$ \\
\hline Fraction Female & $\begin{array}{c}-.48 \\
(17.71)\end{array}$ & $\begin{array}{l}-.06 \\
(.75)\end{array}$ & $\begin{array}{c}1.65 \\
(13.51)\end{array}$ \\
\hline $\begin{array}{l}\text { \# Strikes in } \\
\text { state/year/industry } \\
\text { cells (100s) }\end{array}$ & $\begin{array}{c}.02 \\
(2.50)\end{array}$ & $\begin{array}{c}-.13 \\
(5.21)\end{array}$ & $\begin{array}{c}-.21 \\
(5.55)\end{array}$ \\
\hline $\begin{array}{l}\text { Observations } \\
\mathrm{R}^{2} \\
\text { Mean of Dependent } \\
\text { Variable }\end{array}$ & $\begin{array}{l}12,878 \\
.23 \\
.65\end{array}$ & $\begin{array}{l}12,849 \\
.14 \\
2.04\end{array}$ & $\begin{array}{l}12,850 \\
.23 \\
6.69\end{array}$ \\
\hline $\begin{array}{l}\text { F-test for } 5 \text { Laws } \\
\text { [p-value] }\end{array}$ & $\begin{array}{c}2.18 \\
{[.050]}\end{array}$ & $\begin{array}{c}9.87 \\
{[.000]}\end{array}$ & $\begin{array}{c}3.97 \\
{[.001]}\end{array}$ \\
\hline
\end{tabular}


TABLE 7

Strike Outcomes and the Legal Environment

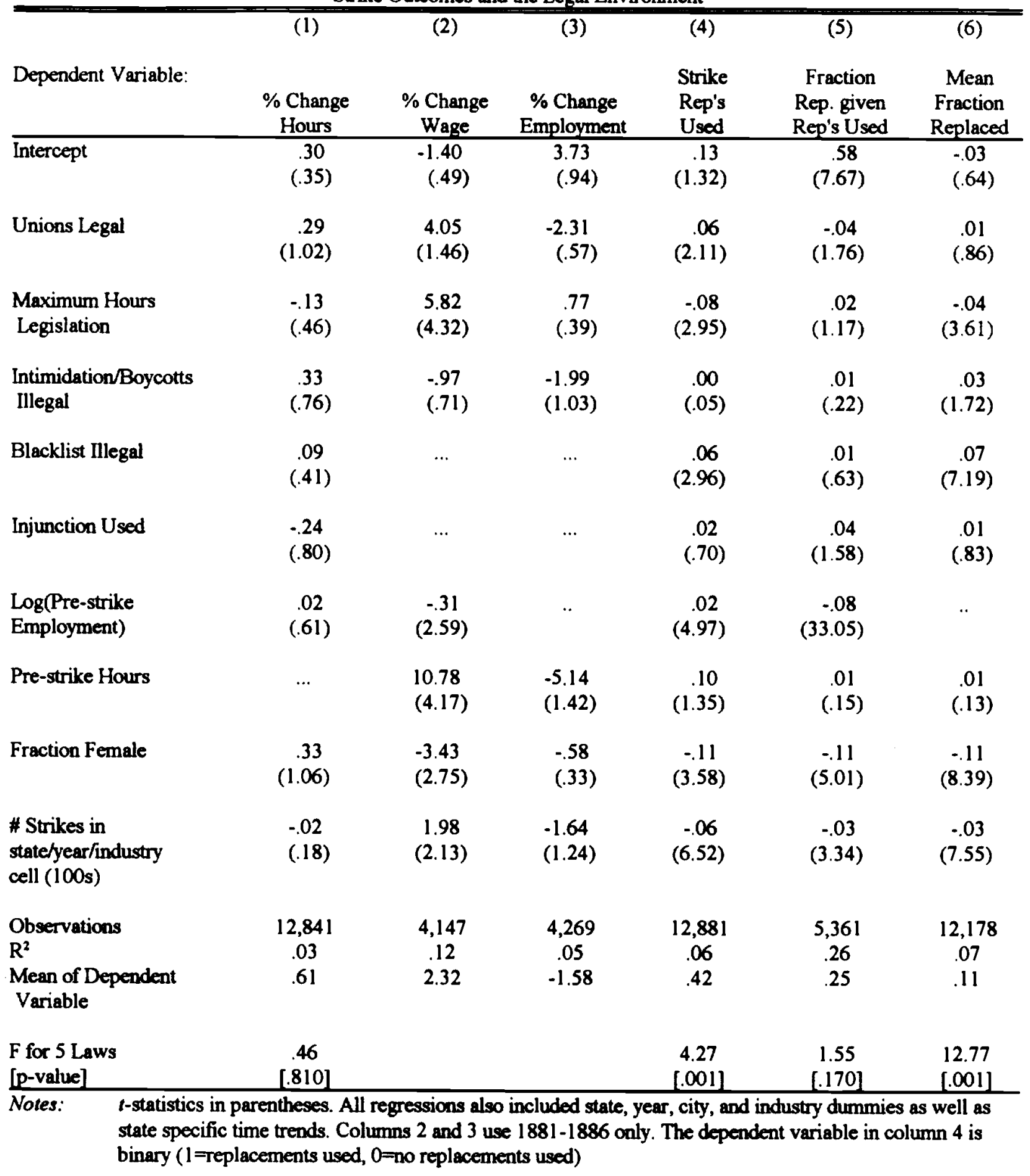




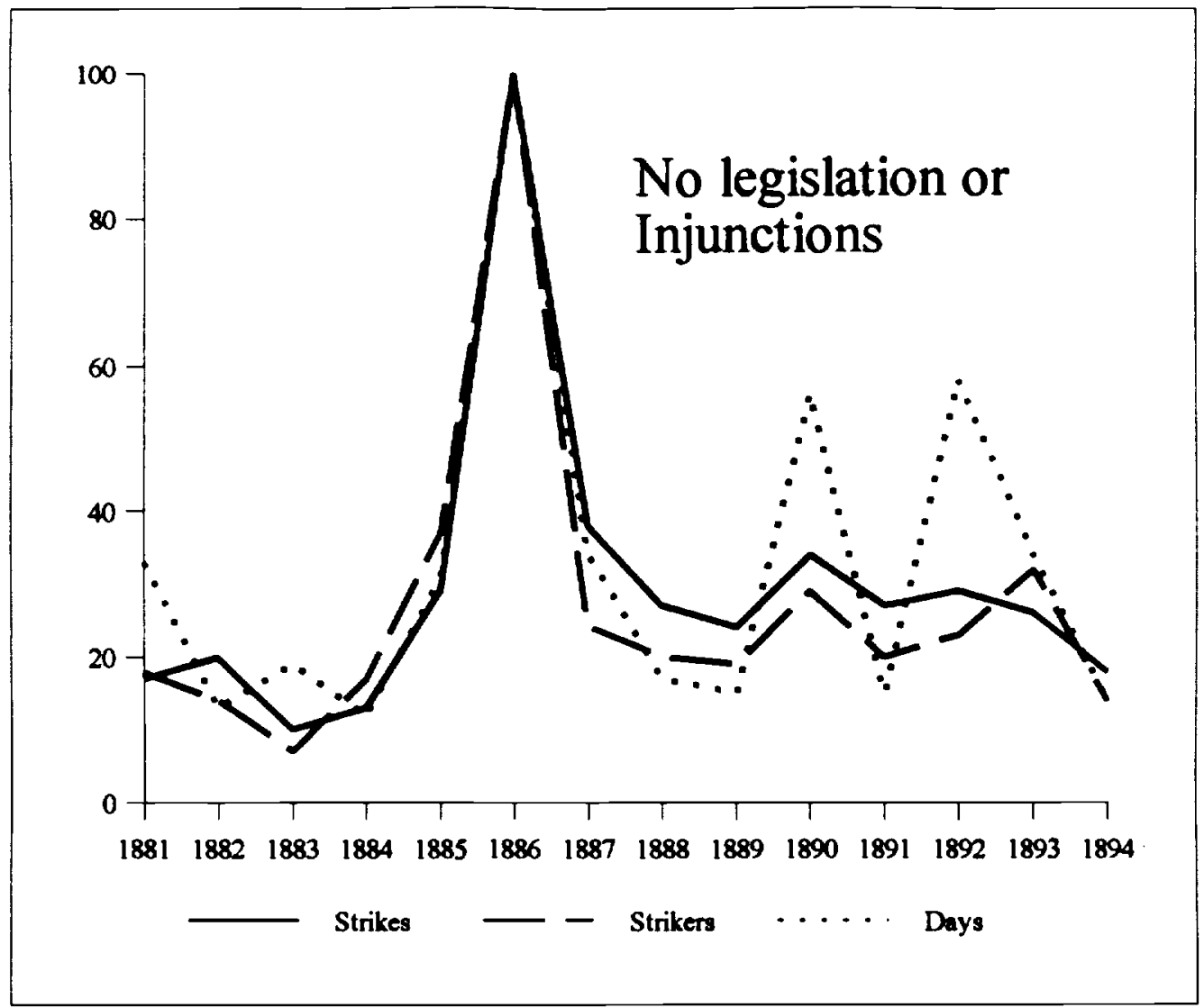

Figure 1: Strike Activity — Connecticut, 1881-1894 (1886=100)

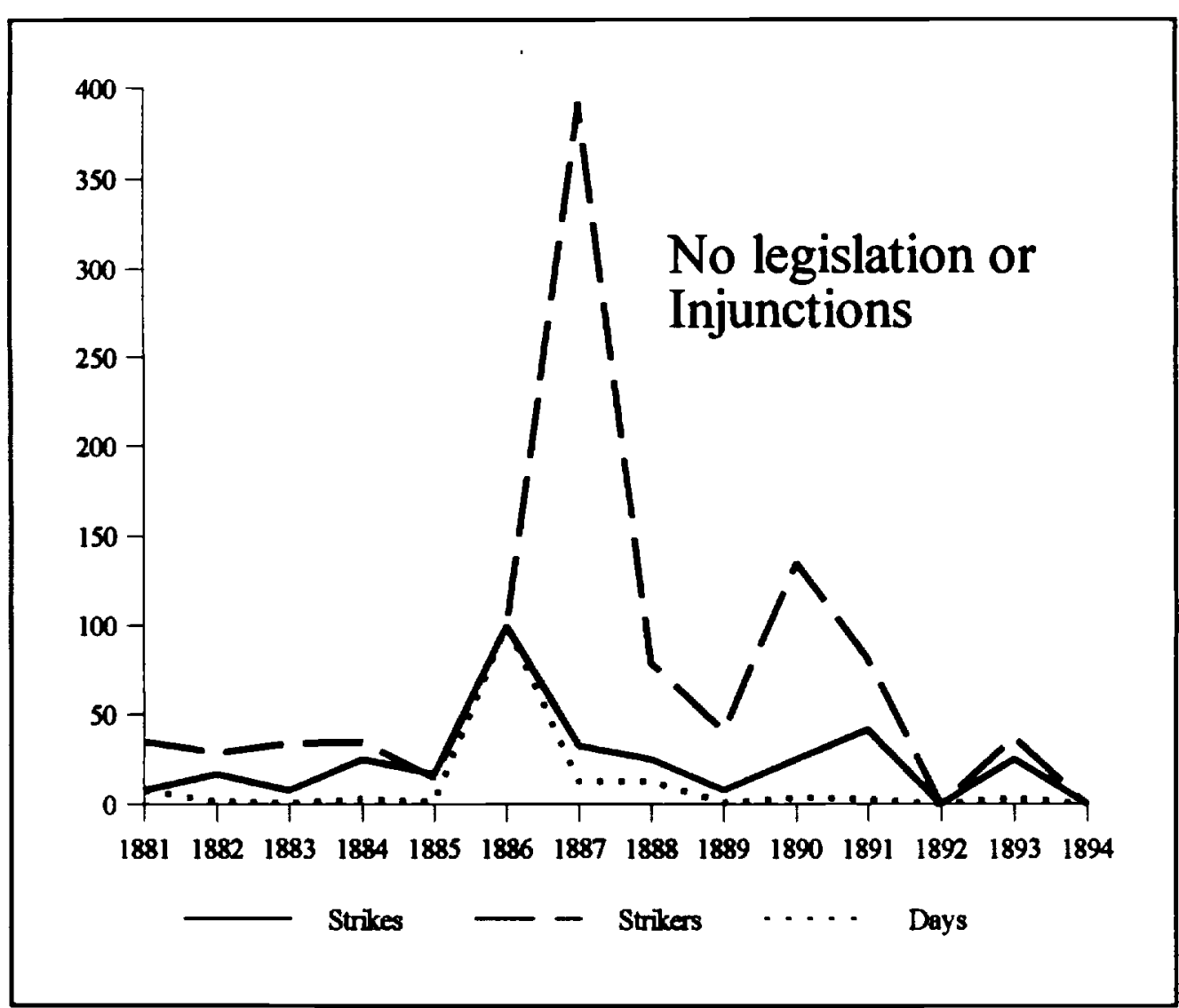

Figure 2: Strike Activity — Delaware, 1881-1894 (1886=100) 


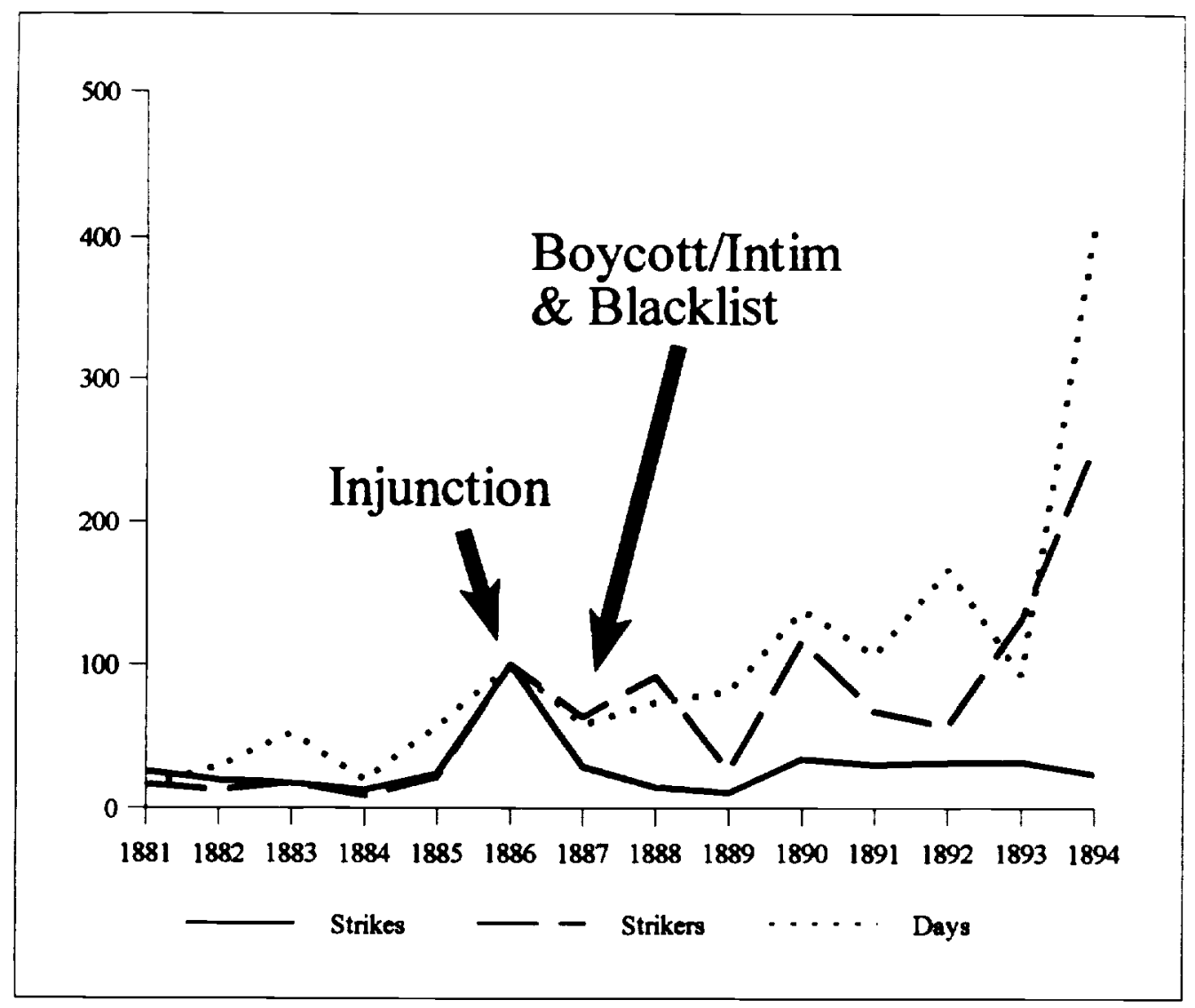

Figure 3: Strike Activity - Illinois, 1881-1894 (1886=100)

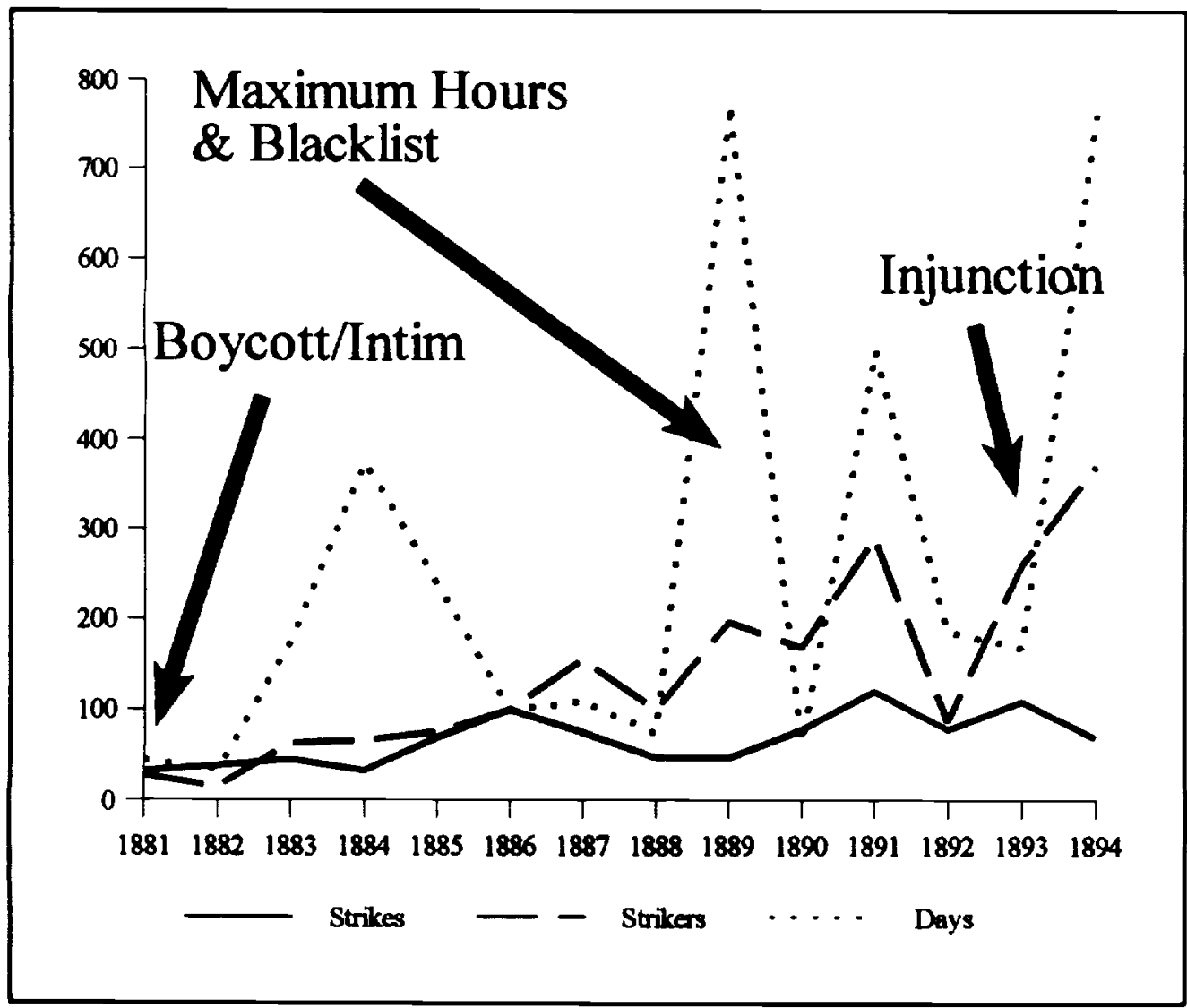

Figure 4: Strike Activity — Indiana, 1881-1894 (1886=100) 


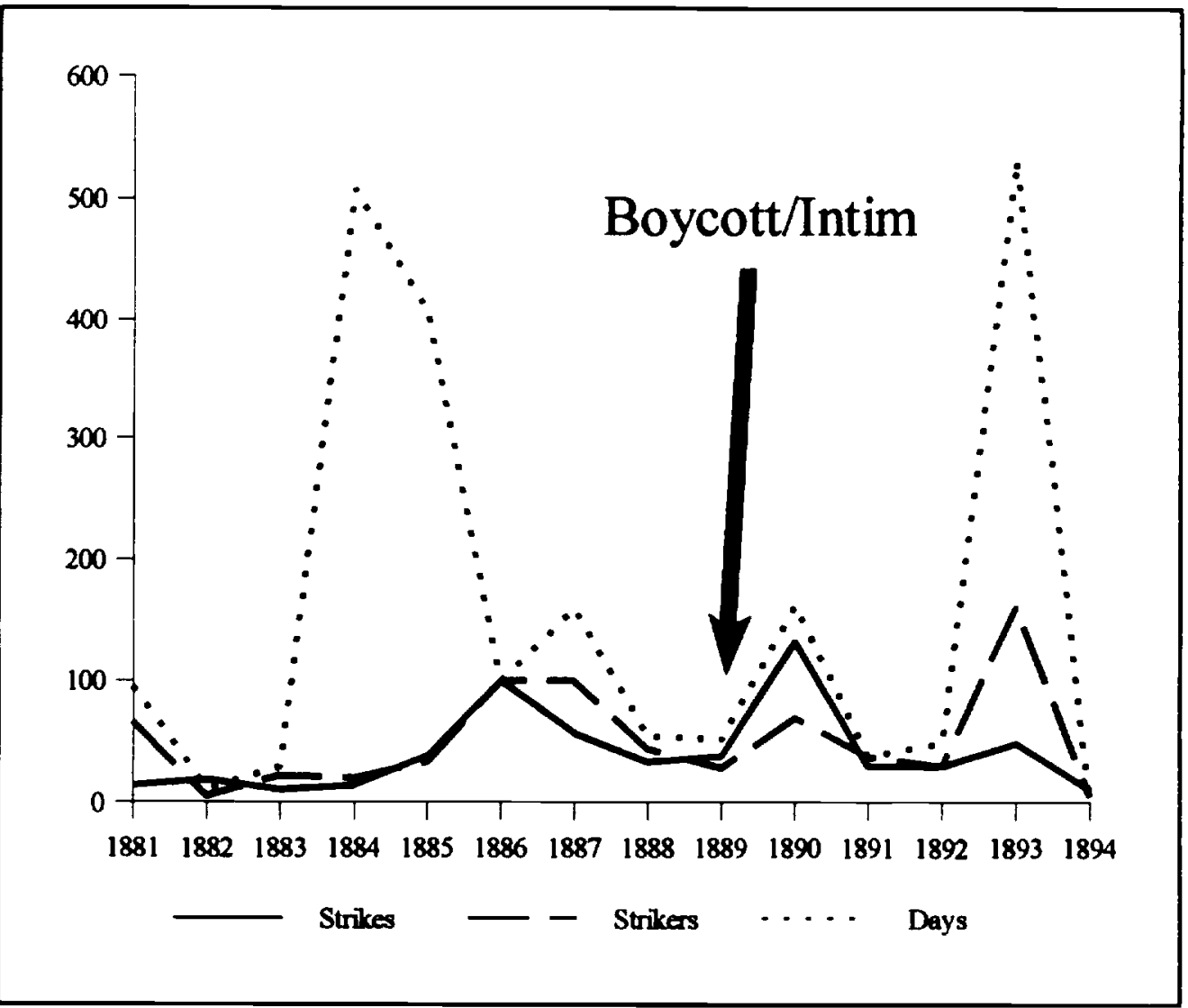

Figure 5: Strike Activity - Maine, 1881-1894 (1886=100)

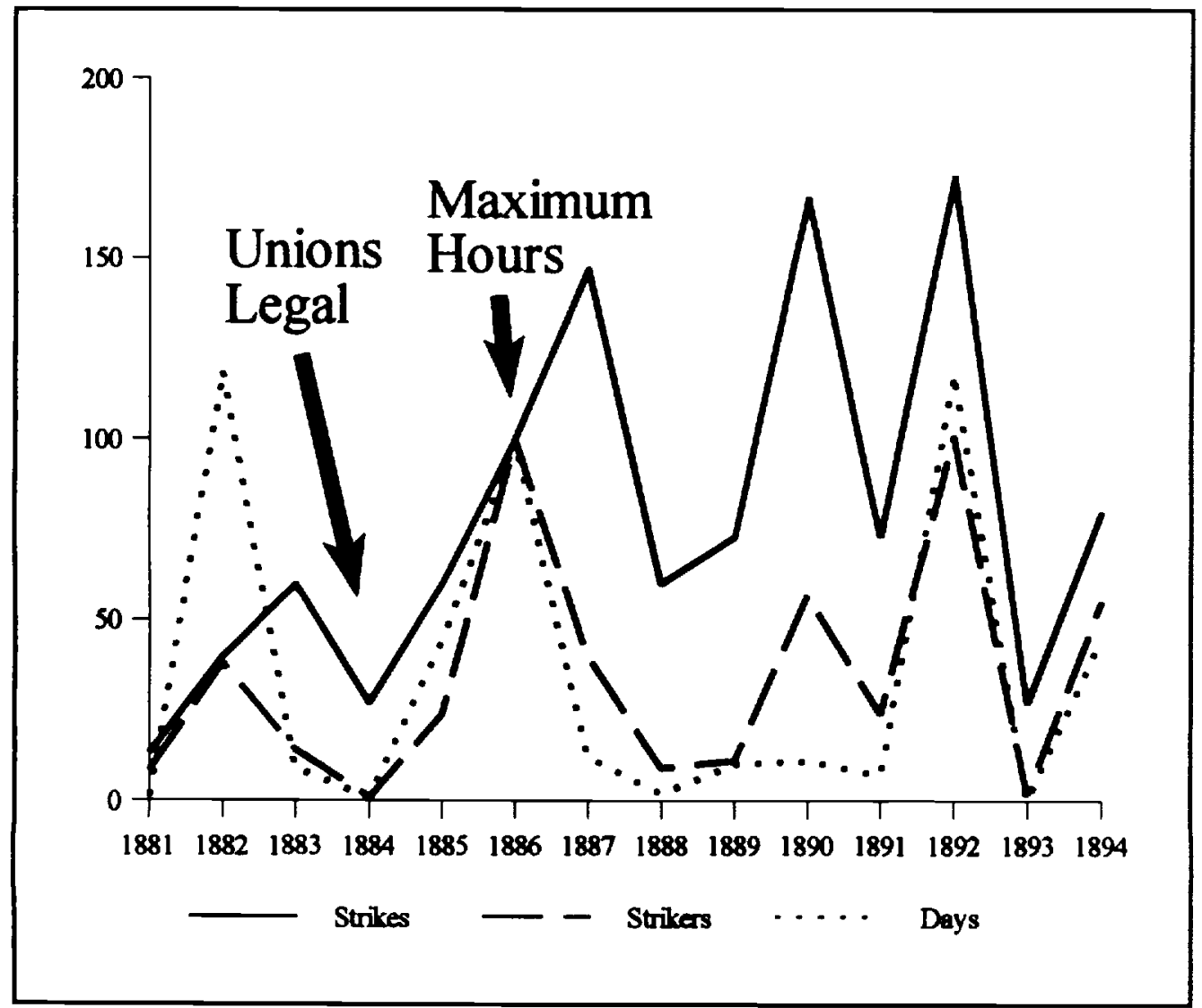

Figure 6: Strike Activity - Maryland, 1881-1894 (1886=100) 


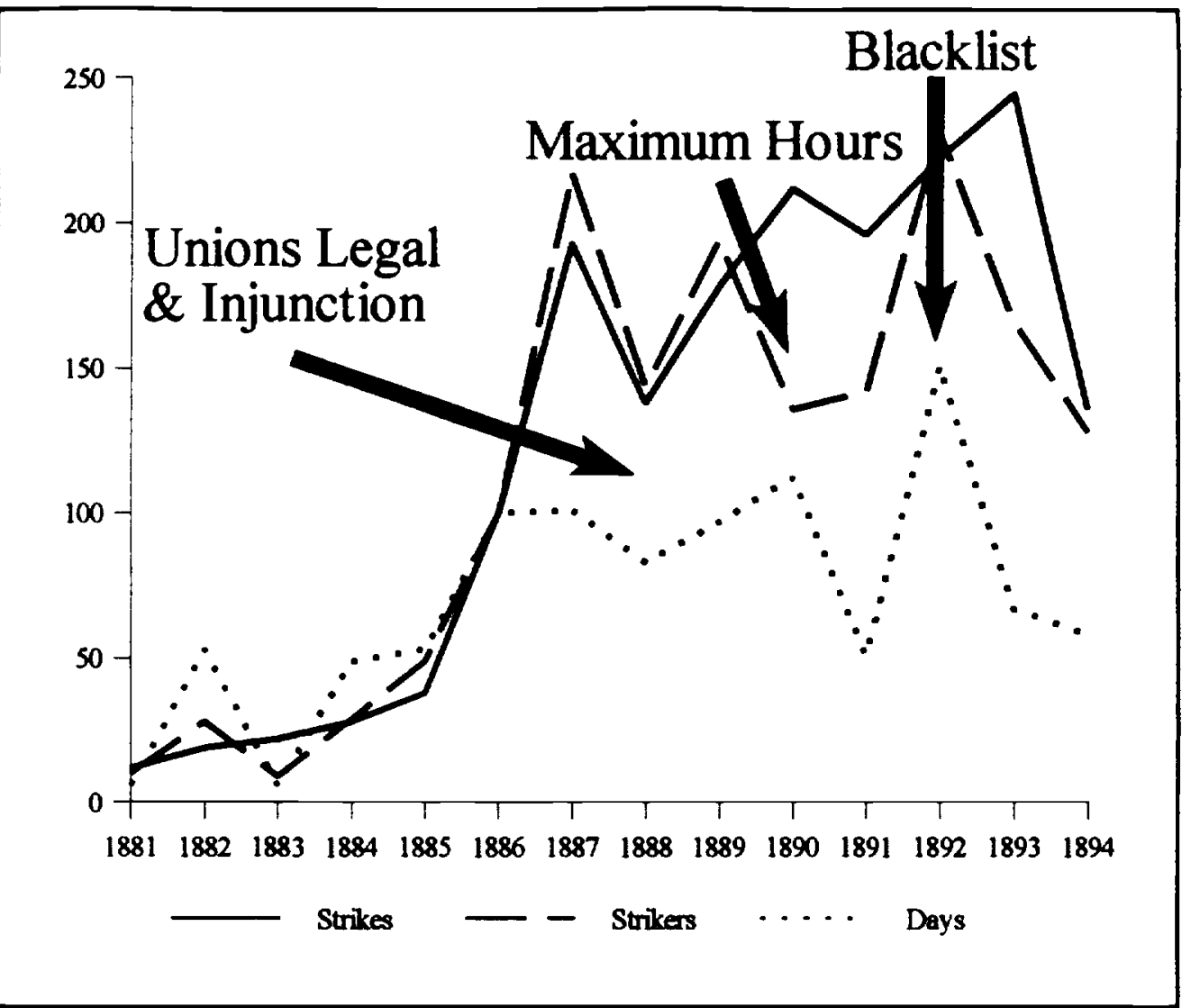

Figure 7: Strike Activity - Massachusetts, 1881-1894 (1886=100)

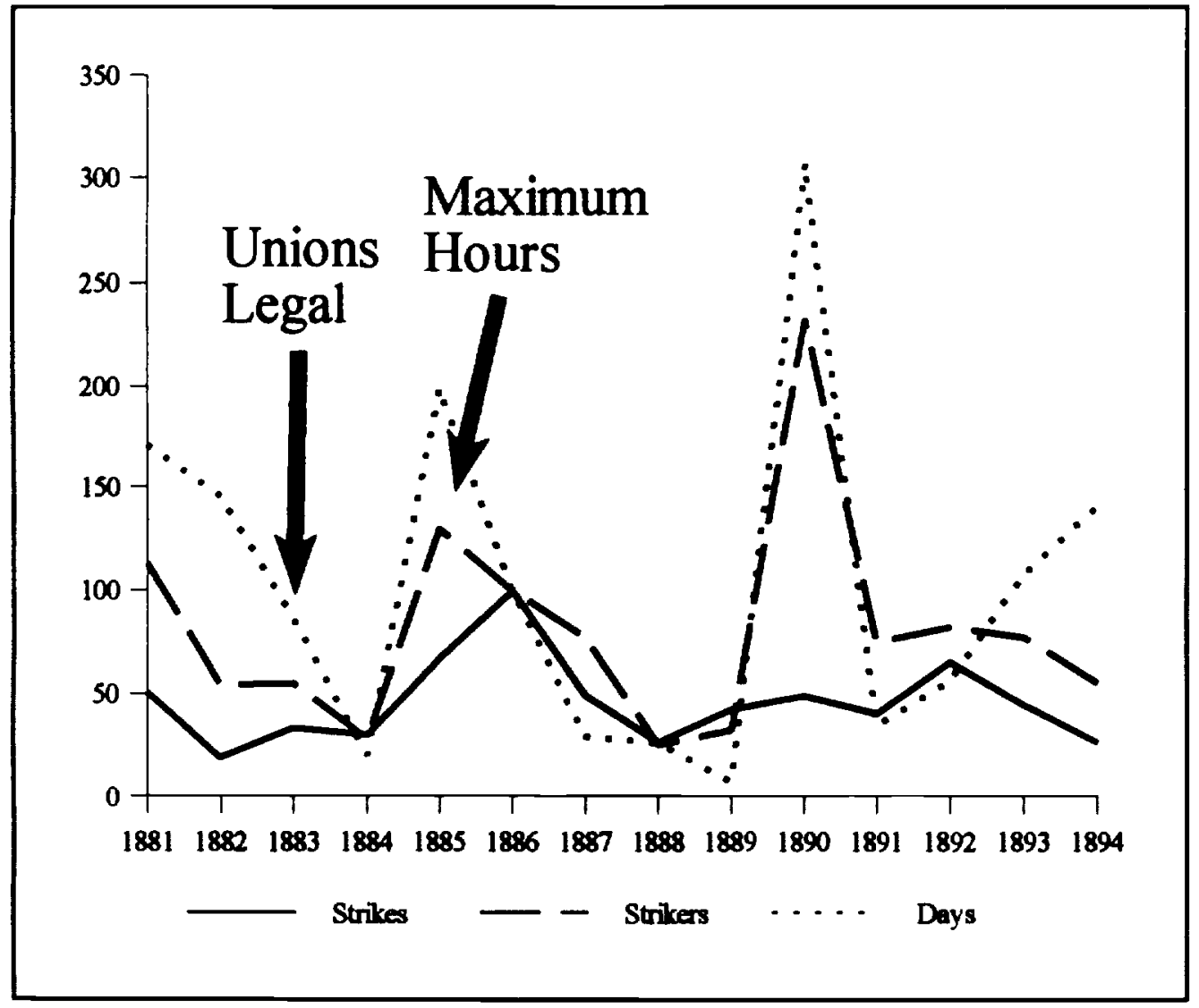

Figure 8: Strike Activity — Michigan, 1881-1894 (1886=100) 


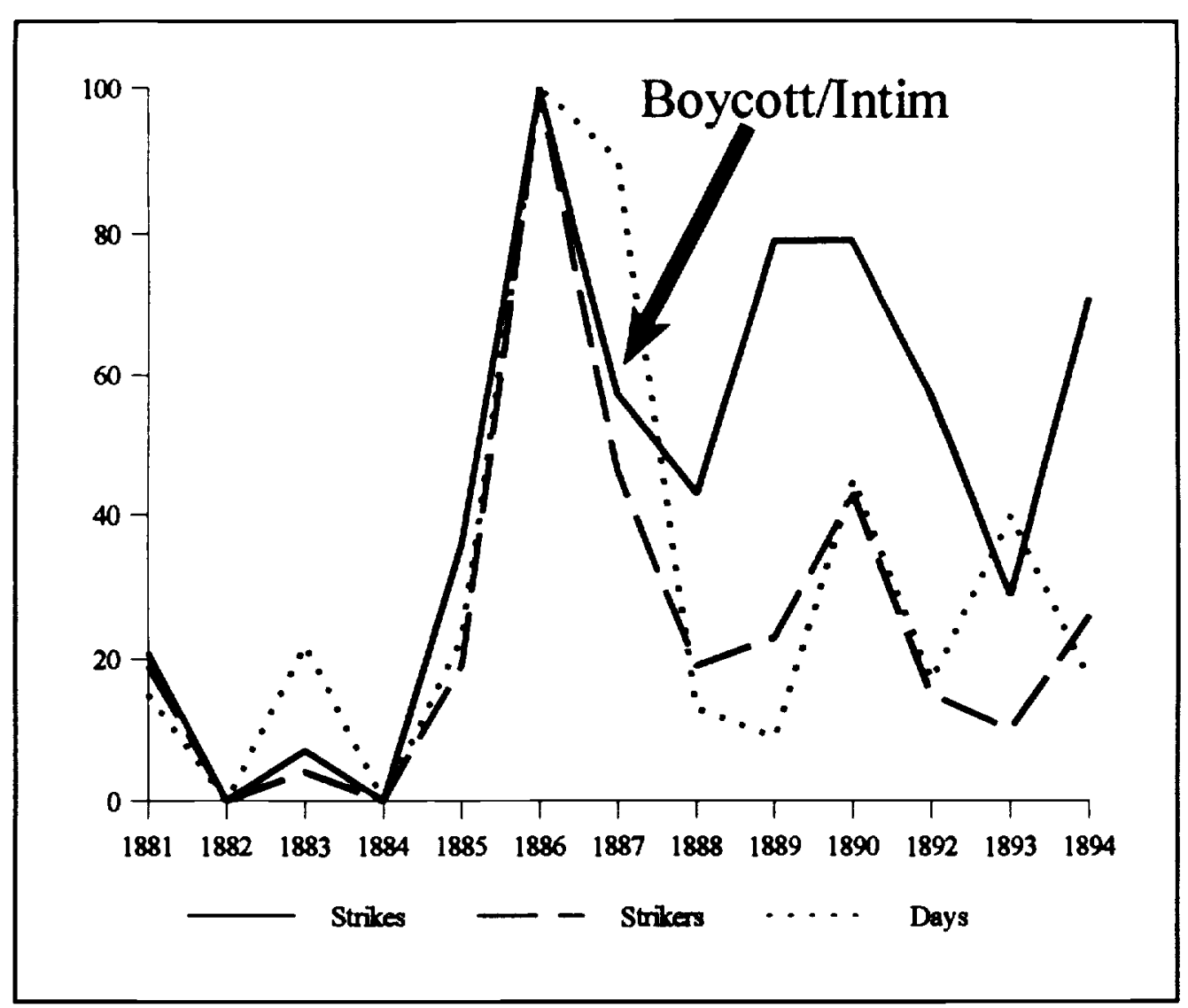

Figure 9: Strike Activity — New Hampshire, 1881-1894 (1886=100)

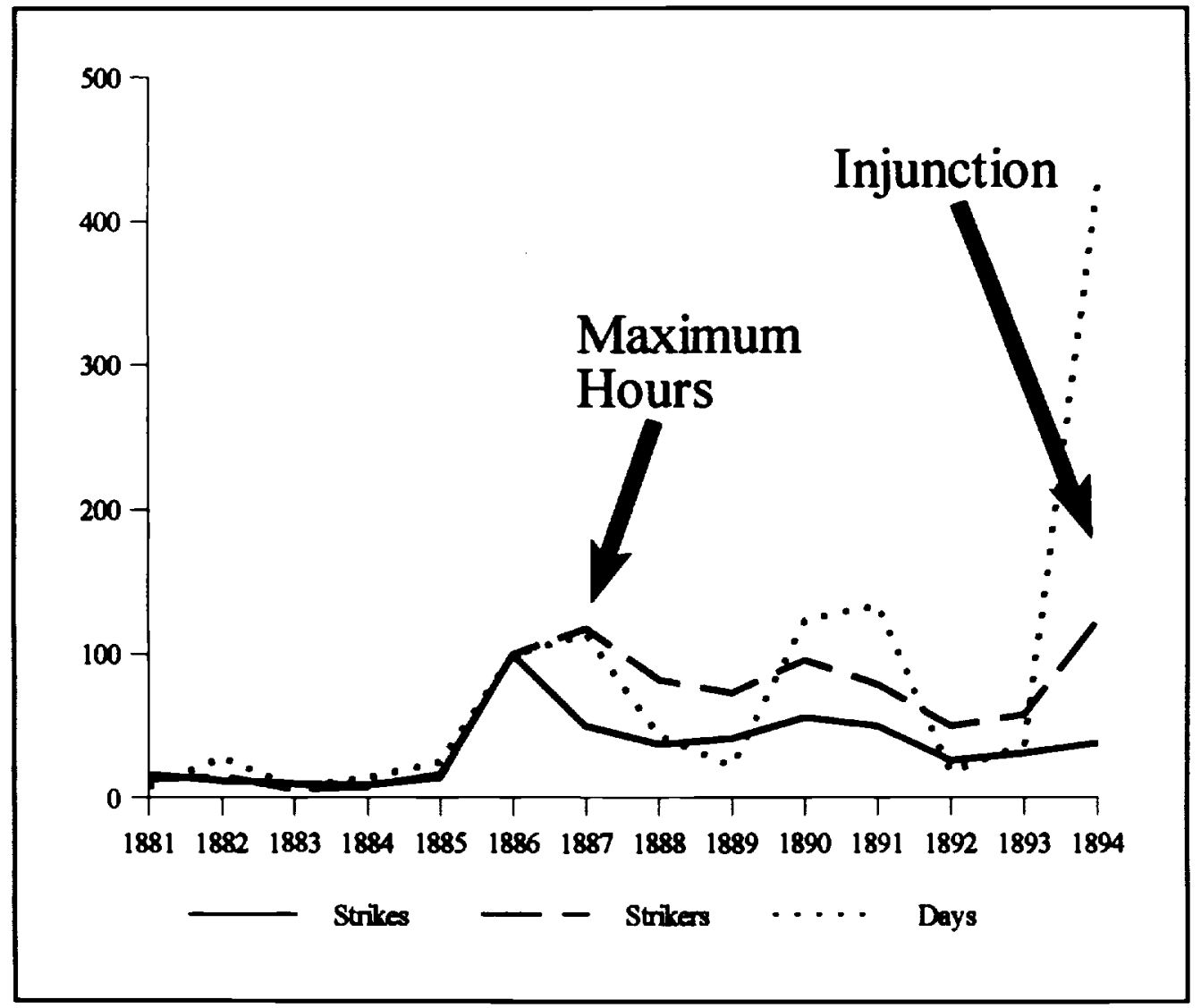

Figure 10: Strike Activity — New Jersey, 1881-1894 (1886=100) 


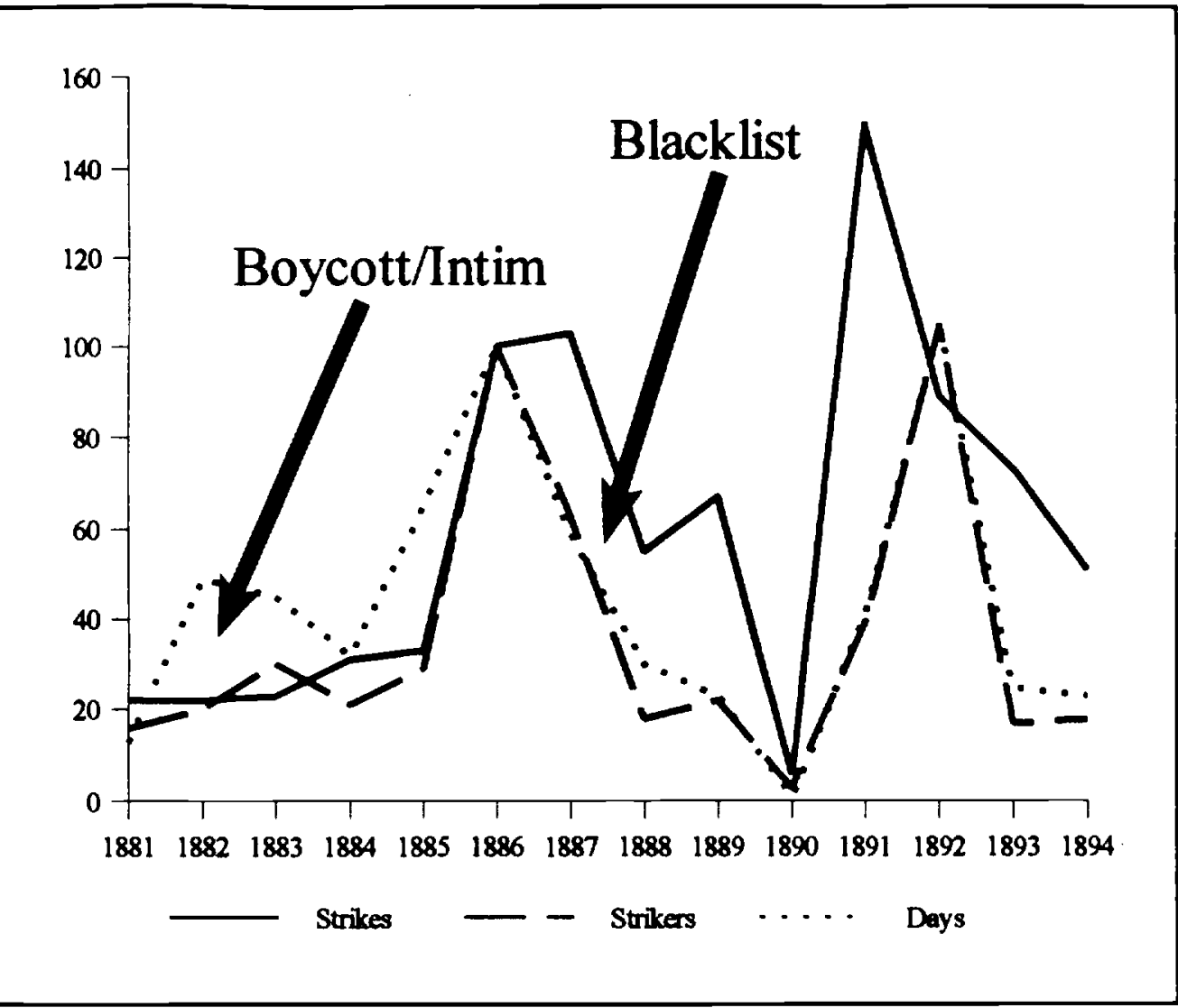

Figure 11: Strike Activity - New York, 1881-1894 (1886=100)

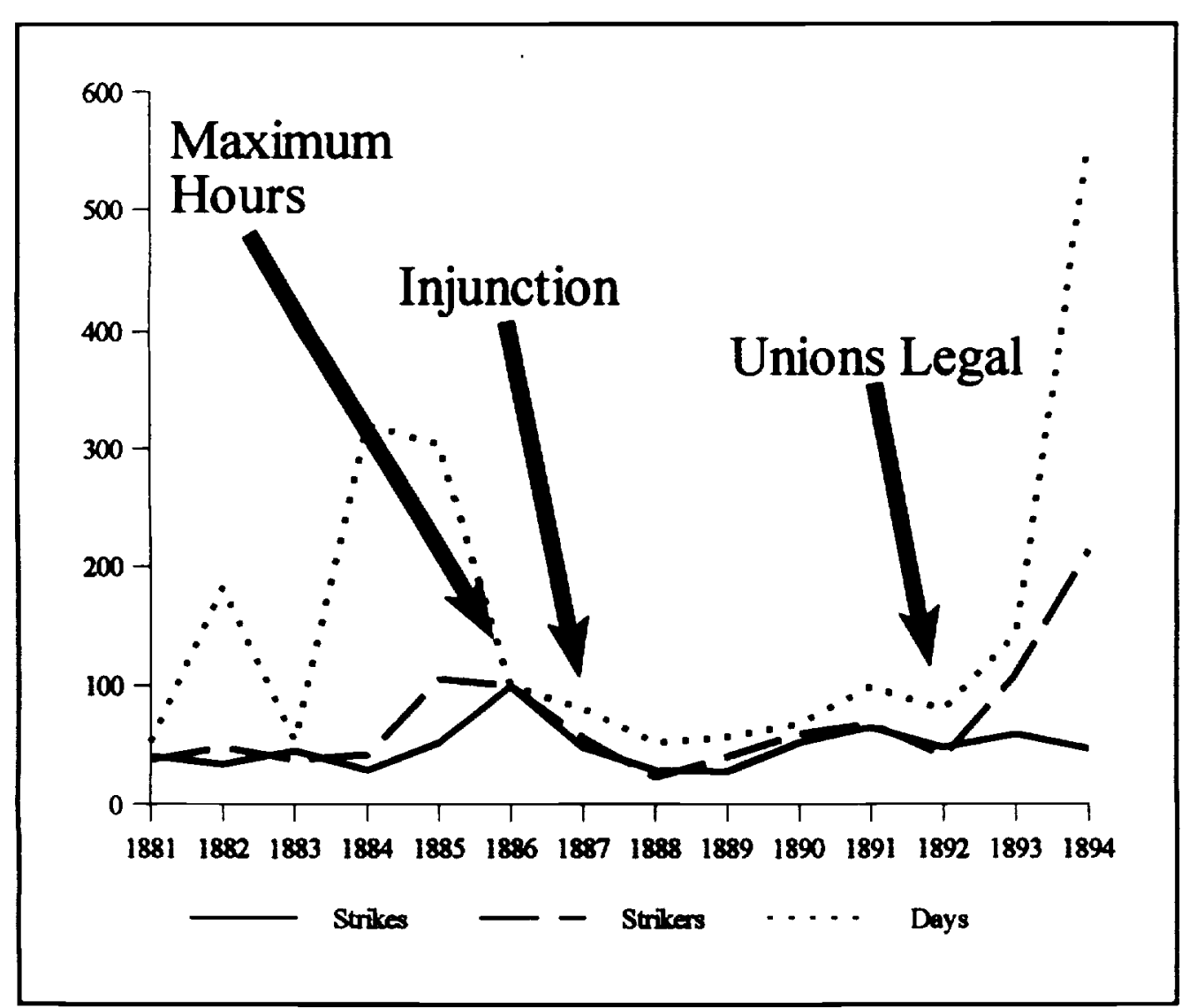

Figure 12: Strike Activity - Ohio, 1881-1894 (1886=100) 


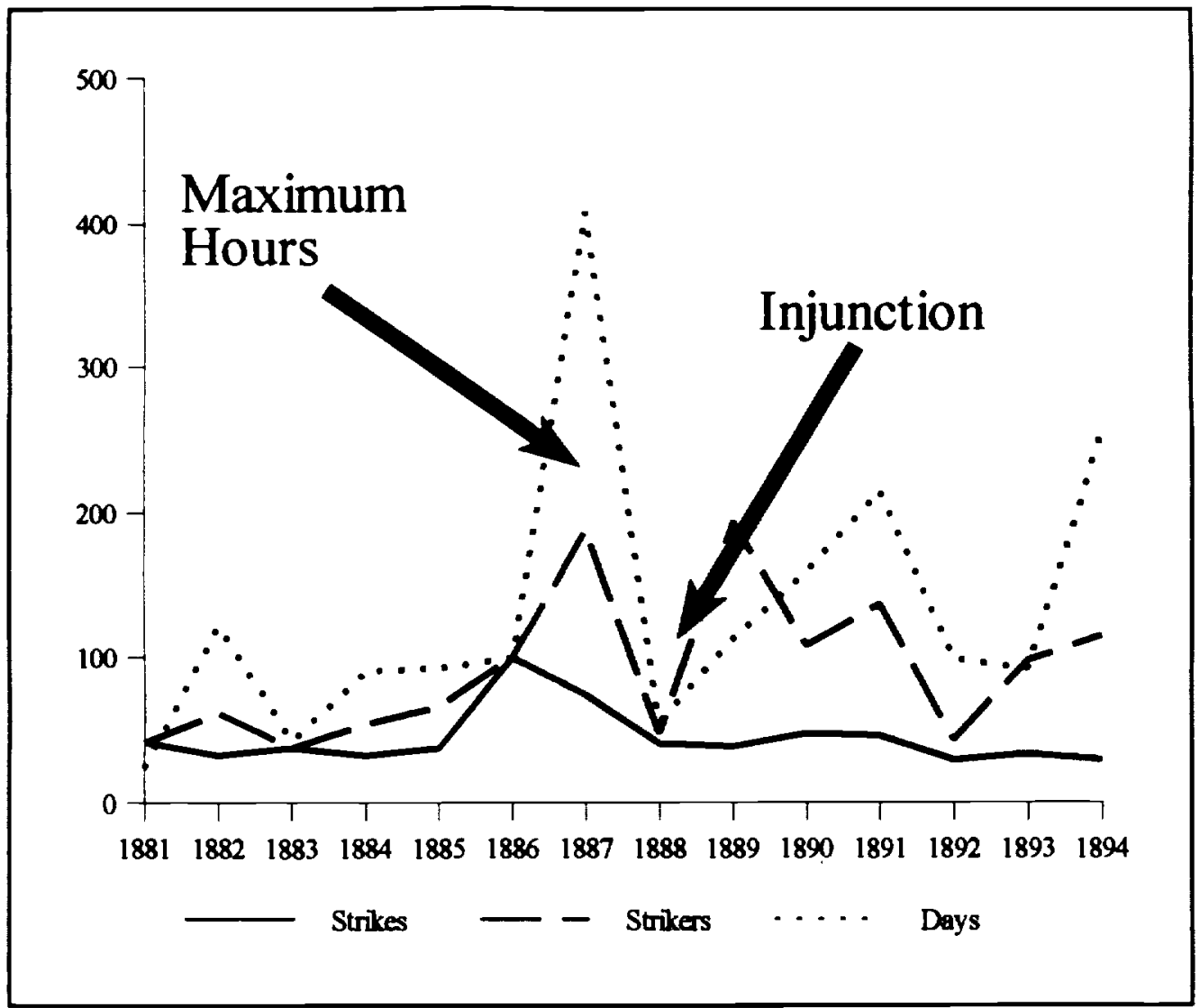

Figure 13: Strike Activity - Pennsylvania, 1881-1894 (1886=100) 